\title{
Prognostic value of key genes of the JAK-STAT signaling pathway in patients with cutaneous melanoma
}

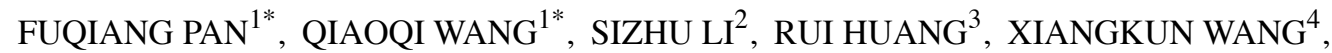 \\ XIWEN LIAO ${ }^{4}$, HAIYAN MO ${ }^{1}$, LIMING ZHANG ${ }^{1}$ and XIANG ZHOU ${ }^{1}$ \\ ${ }^{1}$ Department of Medical Cosmetology, The Second Affiliated Hospital of Guangxi Medical University; \\ Departments of ${ }^{2}$ Medical Oncology, ${ }^{3}$ Hematology and ${ }^{4}$ Hepatobiliary Surgery, The First Affiliated Hospital of \\ Guangxi Medical University, Guangxi Zhuang Autonomous Region 530000, P.R. China
}

Received February 14, 2019; Accepted November 22, 2019

DOI: $10.3892 / 01.2020 .11287$

\begin{abstract}
The Janus kinase-signal transducer and activator of transcription (JAK-STAT) signaling pathway is involved in cell immunity, division and death, as well as in tumor formation. The expression of key genes in the JAK-STAT signaling pathway in different types of cancer serves different roles. However, few reports are available on the prognostic value of the genes of the JAK-STAT signaling pathway in skin cutaneous melanoma (SKCM). The potential prognostic value of gene expression in the JAK-STAT signaling pathway in patients with SKCM was analyzed in the present study using data obtained from The Cancer Genome Atlas. To predict the potential functions and mechanisms of these genes in SKCM, gene set enrichment analysis (GSEA) and bioinformatics analysis were performed. A nomogram model including gene expression level and high risk factors was used to predict the risk level of prognostic. High expression levels of STAT1, STAT3, STAT4 and STAT5B, and low expression levels of STAT6 were associated with favorable prognosis [adjusted $\mathrm{P}<0.001$; hazard ratio (HR), 0.595; 95\% confidence interval (CI), 0.455-0.778; adjusted $\mathrm{P}=0.018$; HR, 0.725; 95\% CI, 0.555-0.947; adjusted $\mathrm{P}<0.001$; HR, 0.590; 95\% CI, 0.450-0.773; adjusted $\mathrm{P}=0.007$; HR, 0.690; 95\% CI, 0.526-0.940; and adjusted $\mathrm{P}=0.026$; HR, 0.737, 95\% CI, 0.563-0.964, respectively]. GSEA results demonstrated that these genes were involved in cell differentiation, invasion, adhesion, migration, cycle, colony formation and mitogen-activated protein kinase signaling. The combination of genes with favorable prognosis had a better effect on
\end{abstract}

Correspondence to: Dr Xiang Zhou, Department of Medical Cosmetology, The Second Affiliated Hospital of Guangxi Medical University, 166 Daxue East Road, Nanning, Guangxi Zhuang Autonomous Region 530000, P.R. China

E-mail: zx_gxmu@hotmail.com

*Contributed equally

Key words: melanoma, Janus kinase-signal transducer and activator of transcription signaling pathway, prognosis the overall survival (univariate survival analysis, $\mathrm{P}<0.05$ ). The results of the present study suggest that STAT1, STAT3, STAT4, STAT5B and STAT6 gene expression may be used as a potential prognostic biomarker of SKCM, and the combined outcomes may exhibit a stronger interaction and higher survival time for SKCM.

\section{Introduction}

Skin cutaneous melanoma (SKCM) is a highly aggressive skin cancer, which arises from the malignant transformation of melanocytes in the basal layer of the epidermis $(1,2)$ and has a poor prognosis, with a 5-year overall survival (OS) of $91.8 \%$ worldwide (3). The number of new cases of SKCM that will emerge in 2019 was estimated to be 96,480 , with the mortality estimated to be $7,230(4,5)$. Therefore, there is an urgent need to identify novel biomarkers and prognostic predictive indicators for the detection and management of SKCM.

The JAK-STAT signaling pathway serves a crucial role in cell immunity, division and death, and in tumor formation (6). The two key components involved in this pathway are Janus kinases (JAKs) and signal transducer and activator of transcription proteins (STATs), which are encoded by the genes JAK (JAK1, JAK2, JAK3 and TYK2) and STAT (STAT1, STAT2, STAT3, STAT4, STAT5A, STAT5B and STAT6), respectively (6).

A previous study has demonstrated that the key genes involved in the JAK-STAT signaling pathway are associated with several types of cancer, including breast $(7,8)$, ovarian, lung, brain (9) and colorectal (10) cancer, and that their differential expression may result in different prognosis outcomes in different types of cancer. However, few reports about the association between these genes and SKCM are available, and further investigation analyzing the prognostic value of gene expression in the JAK-STAT signaling pathway in SKCM is needed. The aim of the present study was to identify the prognostic values of the expression of genes involved in the JAK-STAT signaling pathway in patients with SKCM based on data derived from public databases and bioinformatics analysis, and to explore the underlying mechanism that may affect the outcome in SKCM prognosis. 


\section{Materials and methods}

Data preparation. The Cancer Genome Atlas (TCGA; https://cancergenome.nih.gov; accessed on September 10th 2018 was used to obtain the gene expression and clinical data of patients with SKCM, including sex, age and tumor stage. A total of 458 SKCM cases were selected after removing the cases with missing mRNA expression or clinical data and 0 -day survival time.

Functional analysis of key genes in the JAK-STAT signaling pathway. The Kyoto Encyclopedia of Genes and Genomes (KEGG) signaling pathway map was generated using the KEGG website (https://www.kegg.jp; accessed on September 10th 2018 (11-13). Gene ontology (GO) term analysis, including biological function (BP), molecular function (MF) and cellular component (CC), as well as KEGG enrichment analysis for JAK and STAT gene families, were performed using the Database for Annotation, Visualization and Integrated Discovery version 6.8 (DAVID; https://david. ncifcrf.gov/tools.jsp; accessed on September 13th 2018. The official gene symbol was used as the identifier; the species was Homo sapiens $(14,15)$.

Gene interaction and association analysis. Gene-gene interaction analysis was performed using gene multiple association network integration algorithm (GeneMANIA; http://genemania.org; accessed on September 15th 2018 using the default parameters $(16,17)$. The correlation between JAK and STAT pathway gene expression in SKCM was evaluated using the Pearson's correlation coefficient; $\mathrm{P}<0.01$ was considered to indicate a significant correlation. Protein-protein interaction analysis was performed using the Search Tool for the Retrieval of Interacting Genes/Proteins (STRING; https://string-db.org; accessed on September 25th 2018. The minimum required interaction score was $0.400(18,19)$.

Patient grouping based on gene expression level. Patients with SKCM were divided into high or low expression groups using the median value, and the vertical scatter plots were generated.

Survival analysis. Kaplan-Meier survival plots with log-rank test were used to evaluate the OS for the high and low-expression groups of each gene and clinicopathological characteristics. In addition, the Cox proportional hazard regression model was used for univariate and multivariate survival analyses, and 95\% confidence intervals (CIs) and hazard ratios (HRs) were calculated. Joint effects analysis was performed for the combination of genes identified as significant by the survival analysis.

Nomogram. A nomogram was used to evaluate the association between JAK and STAT gene expression and clinical information in SKCM. In addition, the risk rank for each gene and clinicopathological characteristic, including age, sex and tumor stage, was evaluated by the risk points and total points. Survival rates (1-, 3- and 5-year) were also scored. A high score was associated with a low survival rate.
Gene set enrichment analysis (GSEA). To investigate the potential underlying mechanism of the differential expression of STAT1, STAT3, STAT4, STAT5B and STAT6 in SKCM, GSEA version 3.0 software (http://software.broadinstitute. org/gsea/msigdb/index.jsp; accessed on September 20th 2018 (20) was used, and the difference in the expression levels in the low and high-expression groups for each gene was analyzed with reference gene sets, which were based on the Molecular Signatures Database sets c2 (KEGG gene sets, c2.all.v6.2.symbols.gmt), c5 [Gene Ontology (GO) gene sets, c5.all.v6.2.symbols.gmt] and c6 (oncogenic signatures gene sets, c6.all.v6.2.symbols.gmt) (21). The permutation number was set to 1,000 . Those enrichment gene sets revealed by GSEA as exhibiting a nominal $\mathrm{P}<0.05$ and a false discovery rate (FDR) $<0.25$ were considered to indicate a statistically significant difference. The default parameters were used in GSEA software.

Statistical analysis. Statistical analysis was performed using SPSS v.25.0 software (IBM Corp.) and R 3.3.5 (https://www.r-project.org/). Kaplan-Meier survival analysis and the log-rank test were used to calculate the OS and $\mathrm{P}$-values for all associations. The Cox proportional hazards regression model was used for univariate and multivariate survival analyses. HRs and 95\% CIs were calculated using the Cox proportional hazards regression model with adjustment for influential clinical characteristics such as race, sex, age, Tumor-Node-Metastasis stage (22) and body mass index. FDRs in the GSEA were adjusted for multiple testing with the Benjamini-Hochberg procedure to control the FDR $(23,24)$. $\mathrm{P}<0.05$ was considered to indicate a statistically significant difference. Vertical scatter plots and survival curves were generated in GraphPad Prism v.7.0 (GraphPad Software, Inc.).

\section{Results}

Clinicopathological characteristics of patients with SKCM. The clinicopathological data of the 458 patients included in the present study are presented in Table I. Race, age and tumor stage were significantly associated with median survival time $(\mathrm{P}=0.003, \mathrm{P}<0.001$ and $\mathrm{P}<0.001$, respectively; Table I). After normalization, only JAK1, STAT1, STAT3, STAT4, STAT5B and STAT6 genes mRNA expression were observed.

Bioinformatics analysis of JAK and STAT genes. The KEGG pathway map of the JAK-STAT signaling pathway is represented in Fig. 1 (KEGG map no. 04630; https://www.genome. jp/dbget-bin/www_bget?pathway:map04630). The GO term and KEGG enrichment analysis for JAK and STAT genes included BP (Figs. S1A and S2A), CC (Figs. S1B and S2B), MF (Figs. S1C and S2C) and KEGG (Figs. S1D and S2D). The DAVID result for the combination of JAK and STAT gene families suggested that the JAK and STAT signaling pathways were associated with cell migration, the mitogen-activated protein kinase (MAPK) cascade, cell differentiation (Fig. 2A), cytosol, cytoplasm (Fig. 2B), DNA binding, ATP binding, signal transducer activity (Fig. 2C), the PI3K-AKT signaling pathway and the pancreatic cancer signaling pathway (Fig. 2D). 
Table I. Survival analysis based on clinical information.

\begin{tabular}{|c|c|c|c|c|c|}
\hline Characteristic & Patients $(n=458)$ & No. of events (\%) & MST (days) & $\operatorname{HR}(95 \% \mathrm{CI})$ & Crude P-value \\
\hline Race & & & & & $0.003^{\mathrm{a}}$ \\
\hline Caucasian & 435 & $210(48.3)$ & 2,454 & 0.337 (0.166-0.687) Ref. & \\
\hline Other & 13 & $8(61.5)$ & 636 & & \\
\hline Unknown & 10 & & & & \\
\hline Sex & & & & & 0.345 \\
\hline Male & 284 & $146(51.4)$ & 2,421 & Ref. 0.872 (0.657-1.158) & \\
\hline Female & 174 & $73(42.0)$ & 2,367 & & \\
\hline Age (years) & & & & & $<0.001^{\mathrm{a}}$ \\
\hline$\leq 60$ & 239 & $115(48.1)$ & 3,196 & $0.587(0.445-0.773)$ Ref. & \\
\hline$>60$ & 219 & $104(47.5)$ & 1,864 & & \\
\hline Tumor stage $^{b}$ & & & & & $<0.001^{\mathrm{a}}$ \\
\hline Early & 231 & $108(46.8)$ & 3,195 & 0.547 (0.411-0.728) Ref. & \\
\hline Advanced & 191 & $96(50.3)$ & 1,927 & & \\
\hline Unknown & 36 & & & & \\
\hline
\end{tabular}

${ }^{a} \mathrm{P}<0.05$. ${ }^{b}$ Due to the small sample size of certain tumor stages, two groups were used to reduce the probability of statistical errors. MST, median survival time; HR, hazard ratio; CI, confidence interval; Ref., reference group.

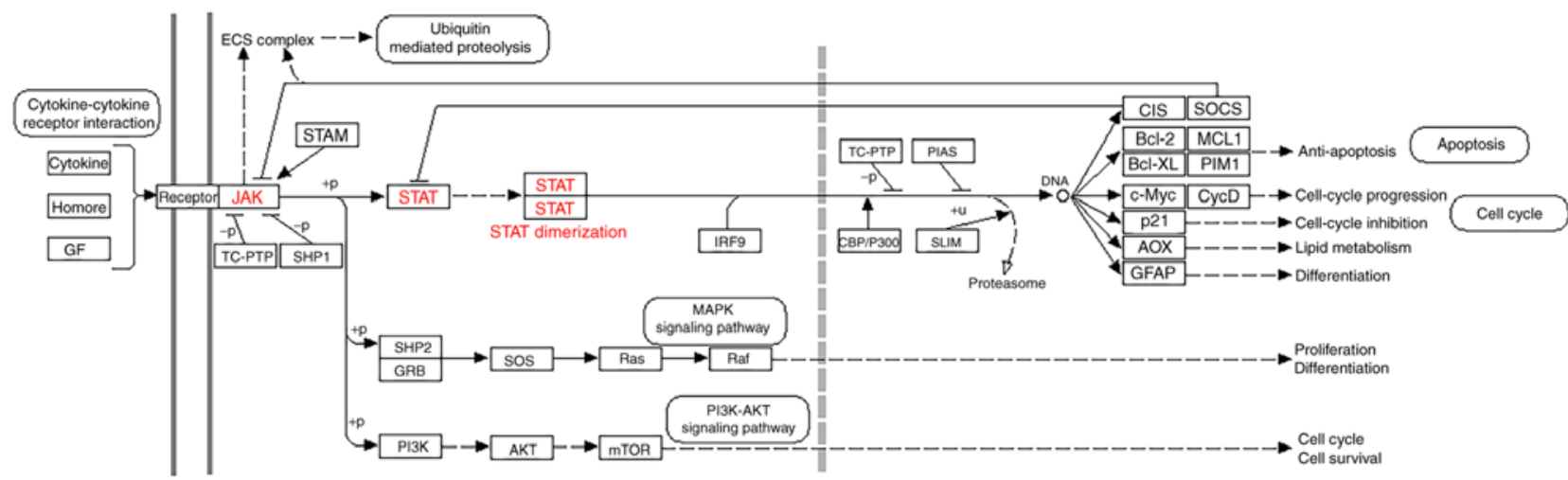

Figure 1. KEGG pathway map of the JAK-STAT signaling pathway obtained from the KEGG website. KEGG, Kyoto Encyclopedia of Genes and Genomes; JAK, Janus kinase; STAT, signal transducer and activator of transcription.

Gene interaction and association analysis. The gene-gene interaction network was analyzed separately in the $J A K$ family (Fig. S3) and in the STAT family (Fig. S4), as well as in their combination (Fig. 3A). The protein-protein interaction network is presented in Fig. 3B.

Pearson's correlation coefficient was used to analyze the correlation between JAK and STAT genes in SKCM tissues based on the TCGA dataset (Fig. 3C). The results suggested that, with the exception of STAT6, the expression of STAT genes (STAT1, STAT3, STAT4 and STAT5B) in SKCM strongly correlated with each other.

Scatter plots of the expression of all JAK and STAT genes in TCGA dataset (using the median as the cut-off value) are presented in Fig. 3D. The difference between the high and low-expression groups was statistically significant $(\mathrm{P}<0.001)$.
Survival analysis. The results of univariate survival analysis of JAK and STAT genes are presented in Fig. 4 and Table II. High expression levels of STAT1, STAT3, STAT4 and STAT5B, and low expression levels of STAT6 were associated with a favorable prognosis $(\mathrm{P}<0.05)$. Multivariate Cox proportional hazards regression analysis identified that sex, race, age and tumor stage were associated with the prognosis of patients with SKCM. Multivariate survival analysis, in agreement with univariate survival analysis, demonstrated that high expression of STAT1, STAT3, STAT4 and $S T A T 5 B$, and low expression of STAT6 was associated with a favorable prognosis (adjusted $\mathrm{P}<0.001$; HR, 0.595; 95\% CI, 0.455-0.778; adjusted $\mathrm{P}=0.018$; HR, 0.725; 95\% CI, 0.555-0.947; adjusted $\mathrm{P}<0.001$; HR, 0.590; 95\% CI, 0.450-0.773; adjusted $\mathrm{P}=0.007$; HR, 0.690; 95\% CI, 0.526-0.940; and adjusted $\mathrm{P}=0.026$; HR, 0.737; 95\% CI, 0.563-0.964, respectively; Table II). 
A

=Regulation of multicellular organism growth =Regulation of cell proliferation घIntracellular signal transduction -MAPK cascade

aMovement of cell or subcellular component

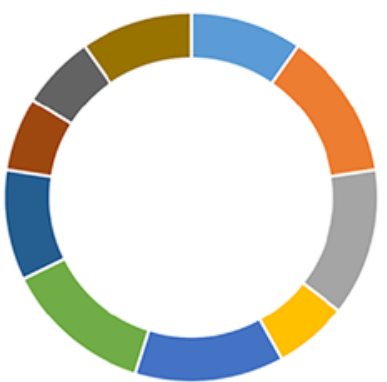

aCell migration

aProtein phosphorylation

-Tumor necrosis factor-mediated signaling pathway aCell differentiation

\title{
Cell differentiation
}

Movement of cell or subcellular component Tumor necrosis factor-mediated signaling pathway MAPK cascade

Protein phosphorylation

Intracellular signal transduction

Positive regulation of growth factor dependent skeletal muscle satellite cell proliferation

Regulation of cell proliferation

Cell migration

Regulation of multicellular organism growth

$$
0
$$

0.51

1.5

2.5

B

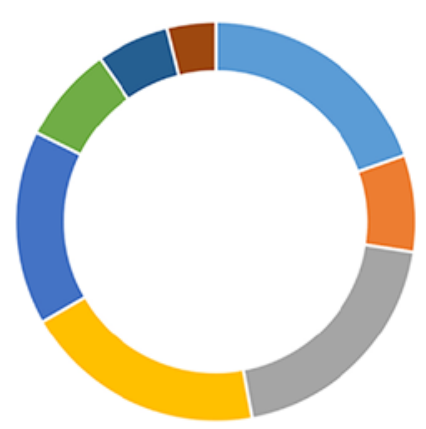

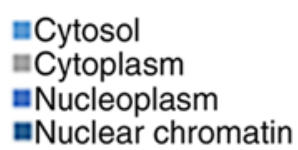

Endomembrane system

Nuclear chromatin

Cytoskeleton

Nucleoplasm

Nucleus

Cytoplasm

Extrinsic component of cytoplasmic side of plasma membrane

Cytosol mucleus

aCytoskeleton

घEndomembrane system
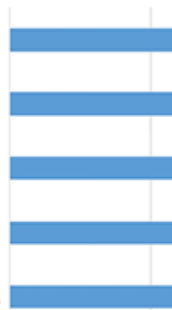$$
\text { - }
$$

0

1

2

3

4

\begin{abstract}
5
\end{abstract}
6

7

Figure 2. Analysis of enriched GO terms and KEGG pathways for JAK and STAT genes obtained using Database for Annotation, Visualization and Integrated Discovery. (A) Biological process results of GO functional enrichment analysis. (B) Cellular component results of GO functional enrichment analysis. 

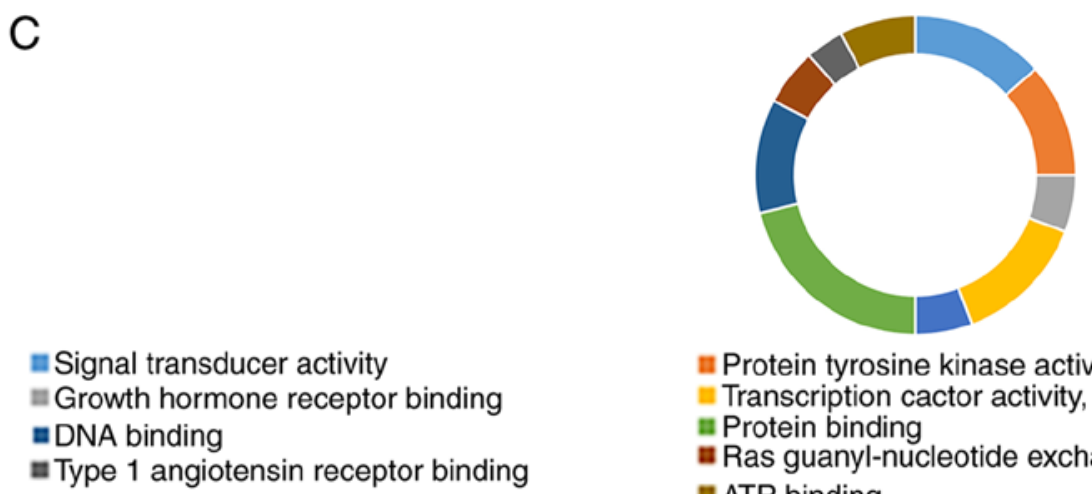

= Protein tyrosine kinase activity

- Transcription cactor activity, sequence-specific DNA binding

= Protein binding

* Ras guanyl-nucleotide exchange factor activity

ATP binding

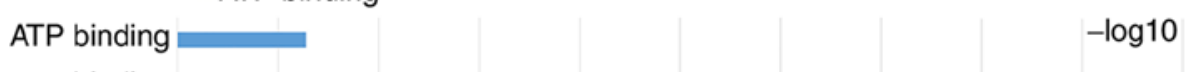

Type 1 angiotensin receptor binding

Ras guanyl-nucleotide exchange factor activity

DNA binding

Protein binding

RNA polymerase II core promoter sequence-specific DNA binding Transcription factor activity,

sequence-specific DNA binding

Growth hormone receptor binding

Protein tyrosine kinase activity

Signal transducer activity

0

1

23

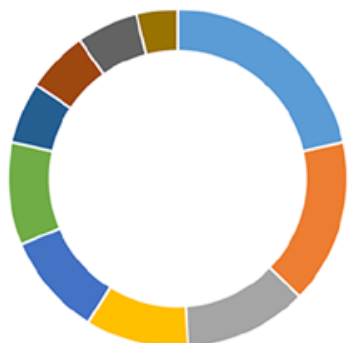

E Jak-STAT signaling pathway

= Hepatitis B

E Chemokine signaling pathway

= Hepatitis C

E Viral carcinogenesis

acute myeloid leukemia

a Pathways in cancer

a PI3K-Akt signaling pathway

Chronic myeloid leukemia

PI3K-Akt signaling pathway

Pancreatic cancer

Acute myeloid leukemia

Pathways in cancer

Viral carcinogenesis

Hepatitis C

Chemokine signaling pathway

Hepatitis B

Jak-STAT signaling pathway

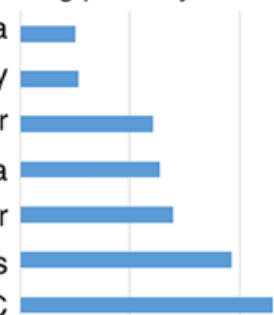

a Pancreatic cancer

a Chronic myeloid leukemia

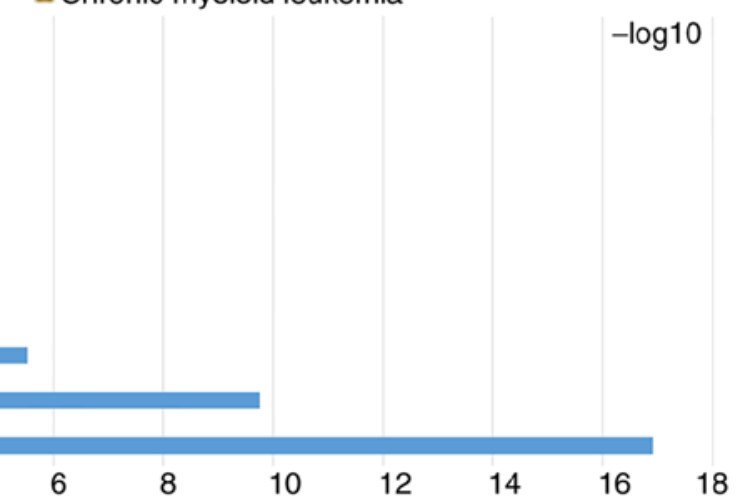

Figure 2. Continued. (C) Molecular function results of GO functional enrichment analysis. (D) KEGG pathway analysis results. GO, Gene Ontology; KEGG, Kyoto Encyclopedia of Genes and Genomes; JAK, Janus kinase; STAT, signal transducer and activator of transcription; MAPK, mitogen-activated protein kinase.

Predictive nomogram and joint effects analysis. Independent factors, including age, sex, tumor stage and mRNA expression, were integrated into the prognostic nomogram to predict the clinical outcomes of patients with SKCM (Fig. 5A). Age, tumor stage, and JAK1, STAT1, STAT4, STAT5B and STAT6 expression levels exhibited major contributions as prognostic signatures in the risk scores (range, $0-100$ ).

All survival related genes, including STATI, STAT3, STAT4, STAT5B and STAT6, were selected and grouped to perform joint effects analysis. The grouping information of joint effects analysis 
A

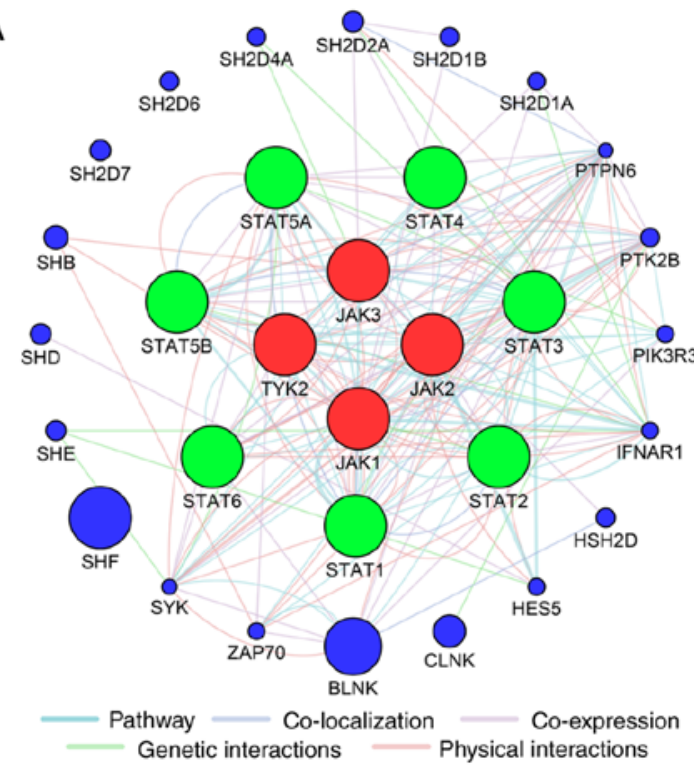

C

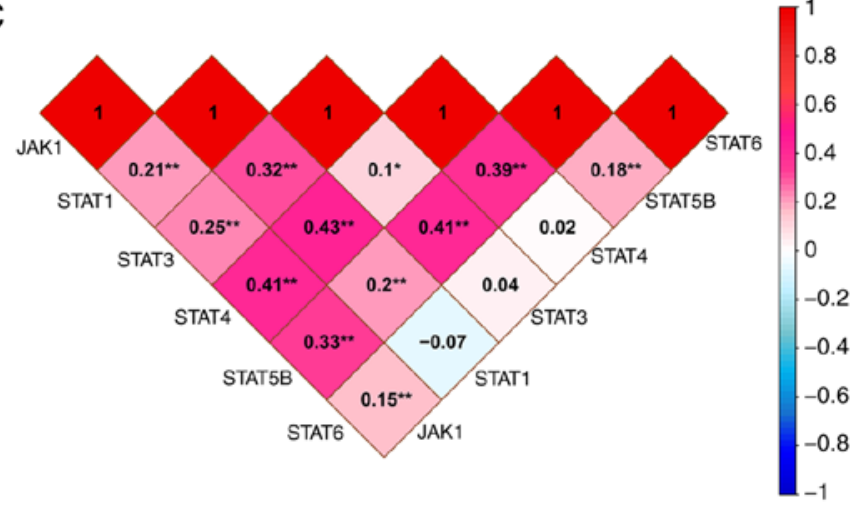

B

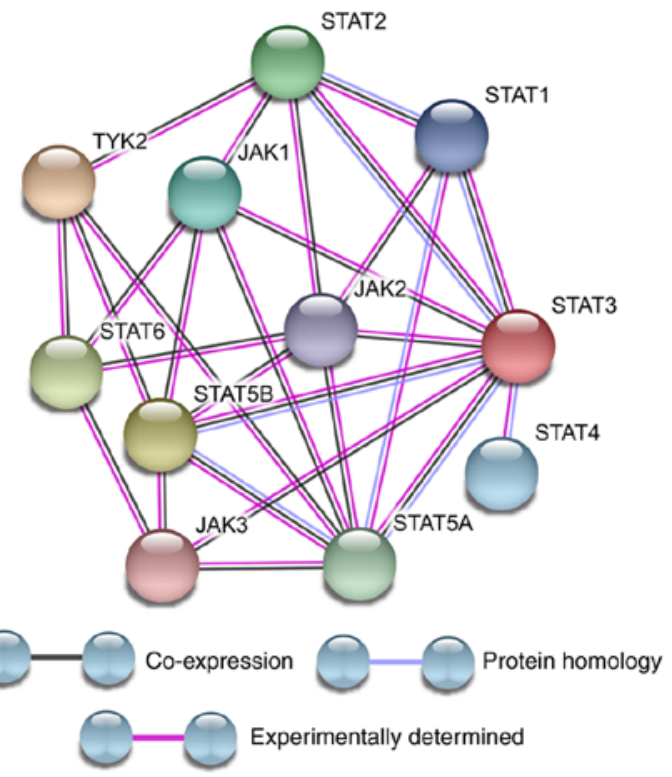

D

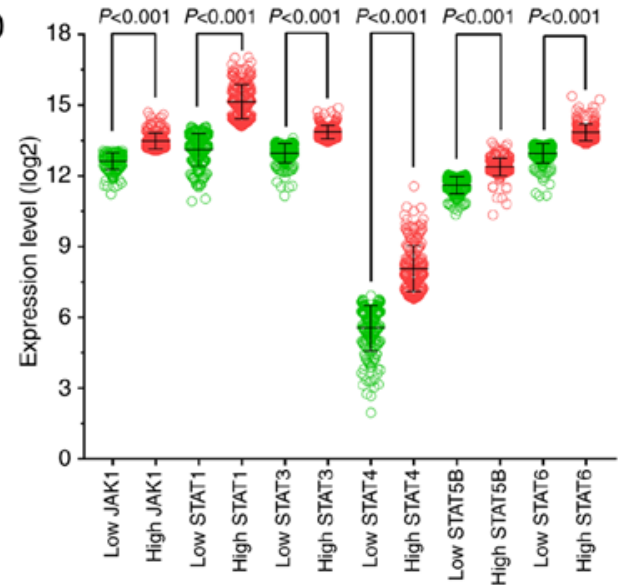

Figure 3. Correlation and association analysis for JAK and STAT genes in SKCM (A) Gene interaction network of JAK and STAT genes generated by GeneMANIA. (B) Protein-protein interaction network generated using the STRING database. (C) Pearson's correlation coefficients for JAK1, STAT1, STAT3, STAT4, STAT5B and STAT6 gene expression levels. (D) Scatter plots of JAK1, STAT1, STAT3, STAT4, STAT5B and STAT6 gene expression level in The Cancer Genome Atlas database. GeneMANIA, gene multiple association network integration algorithm; STRING, Search Tool for the Retrieval of Interacting Genes/Proteins; STAT, signal transducer and activator of transcription; SKCM, skin cutaneous melanoma; error bars in the scatter plots, mean \pm SD.

is presented in Tables III-VI. The group number with simple Arabic numerals represented all gene selected groups (Table III); Arab numerals with brackets are 4 selected genes (Table IV); Lowercase Roman numerals are 3 selected genes (Table V); Capitalized Roman numerals are 2 selected genes (Table VI). The combination of genes with favorable prognosis had a better effect on the OS (univariate survival analysis; $\mathrm{P}<0.05$; Table VII and Figs. 5B-G, 6A-J and 7A-J).

GSEA. The detailed GSEA results, including KEGG, GO and oncogenic signatures, are shown in Tables SI, SII and SIII, respectively, and in Fig. 8. High expression of STAT1 was significantly associated with immune response (normalized $\mathrm{P}=0.002$; FDR=0.243; Fig. 8A), cell adhesion (normalized $\mathrm{P}=0.002$; FDR $=0.206$; Fig. $8 \mathrm{~B}$; normalized $\mathrm{P}=0.010$; FDR $=0.241$; Fig. $8 \mathrm{D})$ and $\mathrm{WNT}$ protein binging (normalized $\mathrm{P}=0.006$; FDR=0.261; Fig. 8C). By contrast, low expression of STAT4 was associated with WNT protein binding (normalized $\mathrm{P}=0.001$; FDR=-0.234; Fig. 8E), whereas high expression of $S T A T 5 B$ was associated with gene silencing (normalized $\mathrm{P}=0.002$; FDR=0.249; Fig. 8F).

\section{Discussion}

In the Surveillance, Epidemiology, and End Results Program database, the 5-year relative survival is $98 \%$ for prostate cancer, $89.9 \%$ for breast cancer and $19.4 \%$ for lung cancer $(3,4)$. For melanoma, a $91.8 \%$ 5-year relative survival rate appears satisfactory; however, the 5-year relative survival for patients with tumor stage IV is only $3 \%(22,25)$.

The JAK-STAT signaling pathway serves a crucial role in functions such as cell proliferation, differentiation, migration and apoptosis, cell survival in hematopoiesis, immune cell development, stem cell maintenance and organismal growth processes (26-28). Dysfunction in the JAK-STAT signaling pathway is associated with diseases such as cancer and immune disorders $(6,27)$. In the JAK-STAT signaling pathway, the $J A K$ family comprises JAK1,JAK2, JAK3 and TYK2, and the STAT 
Table II. Prognostic survival analysis based on high or low expression of JAK and STAT family genes

\begin{tabular}{|c|c|c|c|c|c|c|c|}
\hline Gene & $\begin{array}{l}\text { Patients } \\
(\mathrm{n}=458)\end{array}$ & $\begin{array}{c}\text { No. of } \\
\text { events }(\%)\end{array}$ & $\begin{array}{l}\text { MST } \\
\text { (days) }\end{array}$ & Crude HR (95\% CI) & $\begin{array}{c}\text { Crude } \\
\text { P-value }\end{array}$ & $\begin{array}{l}\text { Adjusted HR } \mathrm{HR}^{\mathrm{b}} \\
\quad(95 \% \mathrm{CI})\end{array}$ & $\begin{array}{l}\text { Adjusted } \\
\text { P-value }^{\text {b }}\end{array}$ \\
\hline \multicolumn{8}{|l|}{$J A K 1$} \\
\hline Low & 229 & $99(43.2)$ & 2,588 & Ref. $1.056(0.808-1.379)$ & 0.690 & Ref. 0.950 (0.720-1.253) & 0.716 \\
\hline High & 229 & $120(52.4)$ & 2,365 & & & & \\
\hline \multicolumn{8}{|l|}{ STAT1 } \\
\hline Low & 229 & $119(52.0)$ & 1,910 & Ref $0.587(0.449-0.767)$ & $<0.001^{\mathrm{a}}$ & Ref. $0.595(0.455-0.778)$ & $<0.001^{\mathrm{a}}$ \\
\hline High & 229 & $100(47.3)$ & 3,259 & & & & \\
\hline \multicolumn{8}{|l|}{ STAT3 } \\
\hline High & 229 & $113(49.3)$ & 2,030 & Ref. $0.701(0.537-0.915)$ & $0.009^{\mathrm{a}}$ & Ref. 0.725 (0.555-0.947) & $0.018^{\mathrm{a}}$ \\
\hline Low & 229 & $106(46.3)$ & 3,080 & & & & \\
\hline \multicolumn{8}{|l|}{ STAT4 } \\
\hline Low & 229 & $121(52.8)$ & 1,785 & Ref. $0.562(0.430-0.735)$ & $<0.001^{\mathrm{a}}$ & Ref. $0.590(0.450-0.773)$ & $<0.001^{\mathrm{a}}$ \\
\hline High & 229 & $98(42.8)$ & 3,176 & & & & \\
\hline \multicolumn{8}{|c|}{ STAT5B } \\
\hline Low & 229 & $117(48.1)$ & 2,022 & Ref. $0.675(0.516-0.884)$ & $0.004^{\mathrm{a}}$ & Ref. $0.690(0.526-0.940)$ & $0.007^{\mathrm{a}}$ \\
\hline High & 229 & $102(47.4)$ & 3,139 & & & & \\
\hline \multicolumn{8}{|l|}{ STAT6 } \\
\hline High & 229 & $115(50.4)$ & 2,184 & Ref. 0.731 (0.559-0.956) & $0.022^{\mathrm{a}}$ & Ref. 0.737 (0.563-0.964) & $0.026^{\mathrm{a}}$ \\
\hline Low & 229 & $104(47.2)$ & 3,139 & & & & \\
\hline
\end{tabular}

${ }^{\mathrm{a} P}<0.05 .{ }^{\mathrm{b}}$ Adjusted for age and tumor stage. JAK1, Janus kinase $1 ;$ STAT, signal transducer and activator of transcription; MST, median survival time; HR, hazard ratio; CI, confidence interval; Ref., reference.
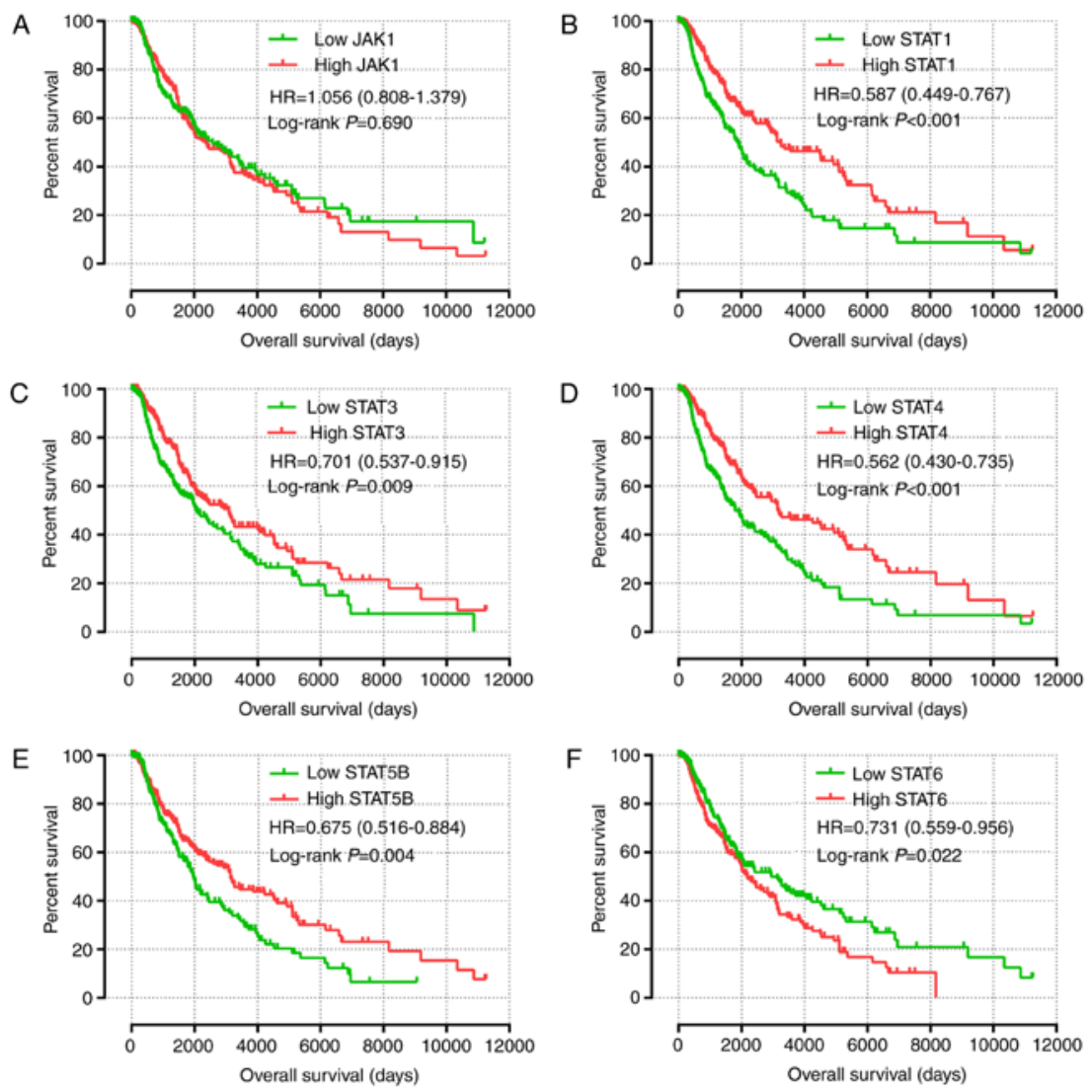

Figure 4. Prognostic value of the expression of key genes of the JAK-STAT signaling pathway for overall survival. (A-F) Kaplan-Meier survival plots for all patients with skin cutaneous melanoma according to (A) JAK1, (B) STAT1, (C) STAT3, (D) STAT4, (E) STAT5B and (F) STAT6 expression. JAK, Janus kinase; STAT, signal transducer and activator of transcription. 
A
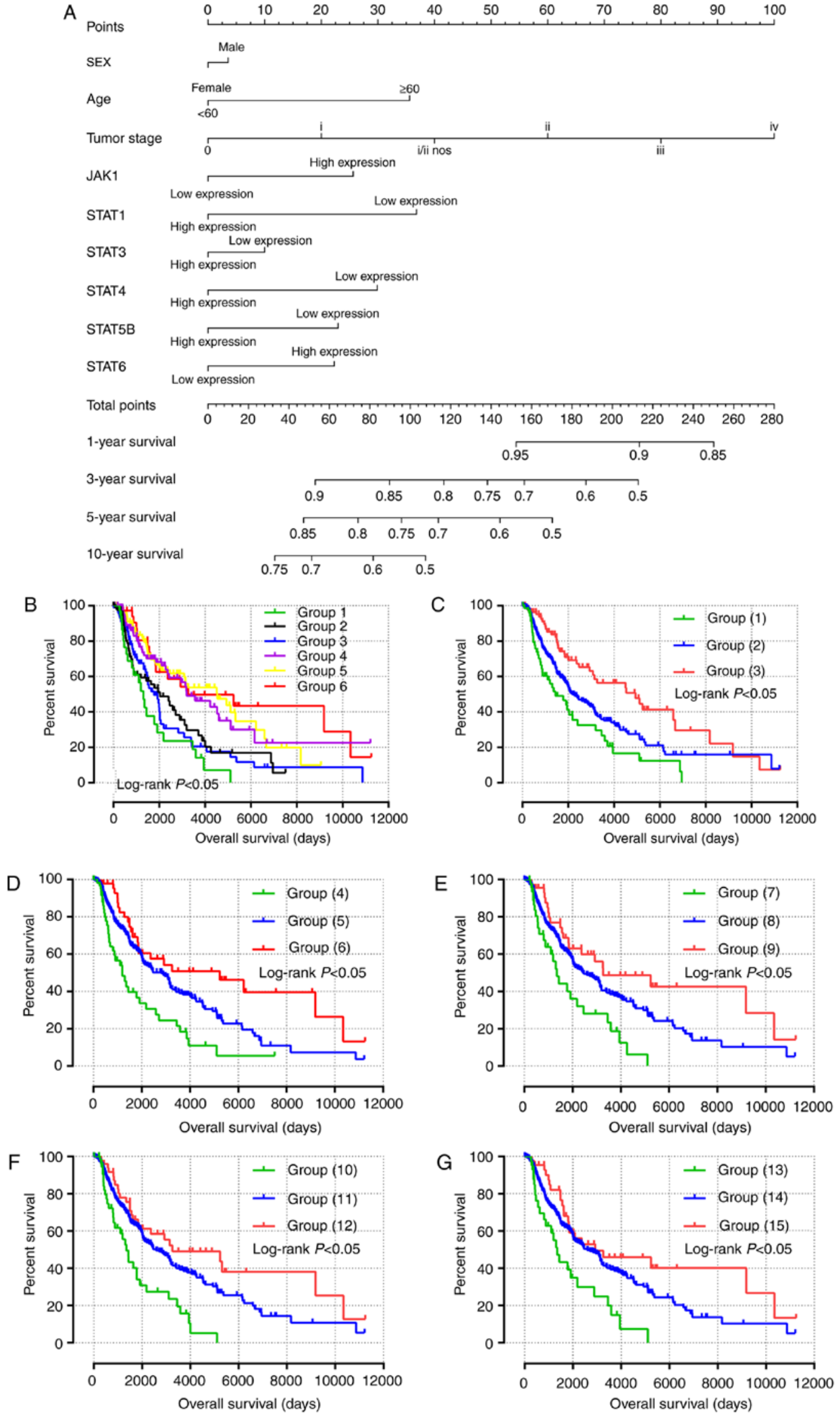

Figure 5. Nomogram and joint-effects survival analysis of JAK and STAT genes. (A) Nomogram for predicting the 1-, 3- and 5-year event (death) based on risk scores and clinical information. (B) Joint effects analysis of the influence of combined gene expression on overall survival in patients with skin cutaneous carcinoma. (C-G) Joint effects analysis of the influence of combined expression of four selected genes on overall survival in patients with skin cutaneous melanoma according to (C) group (1)-(3), (D) group (4)-(6), (E) group (7)-(9), (F) group (10)-(12) and (G) group (13)-(15). JAK1, Janus kinase 1; STAT, signal transducer and activator of transcription. NOS, non-specific. 
Table III. Grouping information for joint effects analysis of all STAT genes.

\begin{tabular}{|c|c|c|c|c|c|}
\hline \multirow[b]{2}{*}{ Group } & \multicolumn{5}{|c|}{ Composition } \\
\hline & STAT1 & STAT3 & STAT4 & STAT5B & STAT6 \\
\hline 1 & Low & Low & Low & Low & High \\
\hline \multirow[t]{5}{*}{2} & High & Low & Low & Low & High \\
\hline & Low & High & Low & Low & High \\
\hline & Low & Low & High & Low & High \\
\hline & Low & Low & Low & High & High \\
\hline & Low & Low & Low & Low & Low \\
\hline \multirow[t]{10}{*}{3} & High & High & Low & Low & High \\
\hline & High & Low & High & Low & High \\
\hline & High & Low & Low & High & High \\
\hline & High & Low & Low & Low & Low \\
\hline & Low & High & High & Low & High \\
\hline & Low & High & Low & High & High \\
\hline & Low & High & Low & Low & Low \\
\hline & Low & Low & High & High & High \\
\hline & Low & Low & High & Low & Low \\
\hline & Low & Low & Low & High & Low \\
\hline \multirow[t]{10}{*}{4} & High & High & High & Low & High \\
\hline & High & High & Low & High & High \\
\hline & High & Low & High & High & High \\
\hline & Low & High & High & High & High \\
\hline & High & High & Low & Low & Low \\
\hline & High & Low & High & Low & Low \\
\hline & Low & High & High & Low & Low \\
\hline & High & Low & Low & High & Low \\
\hline & Low & High & Low & High & Low \\
\hline & Low & Low & High & High & Low \\
\hline \multirow[t]{5}{*}{5} & High & High & High & High & High \\
\hline & High & High & High & Low & Low \\
\hline & High & High & Low & High & Low \\
\hline & High & Low & High & High & Low \\
\hline & Low & High & High & High & Low \\
\hline 6 & High & High & High & High & Low \\
\hline
\end{tabular}

Bold, favorable prognosis groups in univariate survival analysis STAT, signal transducer and activator of transcription.

family comprises STAT1, STAT2, STAT3, STAT4, STAT5A, $S T A T 5 B$ and STAT6 $(6,29)$. A number of diseases are associated with the expression levels of genes of the JAK-STAT signaling pathway. A previous study has demonstrated that increased expression of STAT3 or STAT1, but not of both, was present in melanoma compared with that in benign nevi or skin melanocytes (30). In addition, active STAT3 was present in melanoma (30). By contrast, overexpression of microRNA (miR)-214 in a lung cancer cell line reduced the expression of $J A K l$, which inhibited cell proliferation and colony formation, and suppressed cell migration and invasion (31). In papillary thyroid cancer, downregulation of JAK1 by miR-520a-3p inactivated the JAK-STAT signaling pathway (32).
Table IV. Grouping information for joint effects analysis of four selected STAT genes.

\begin{tabular}{|c|c|c|c|c|c|}
\hline \multirow[b]{2}{*}{ Group } & \multicolumn{5}{|c|}{ Composition } \\
\hline & STAT1 & STAT3 & STAT4 & STAT5B & STAT6 \\
\hline (1) & Low & Low & Low & Low & - \\
\hline \multirow[t]{14}{*}{ (2) } & High & Low & Low & Low & - \\
\hline & Low & High & Low & Low & - \\
\hline & Low & Low & High & Low & - \\
\hline & Low & Low & Low & High & - \\
\hline & High & High & Low & Low & - \\
\hline & High & Low & High & Low & - \\
\hline & High & Low & Low & High & - \\
\hline & Low & High & High & Low & - \\
\hline & Low & High & Low & High & - \\
\hline & Low & Low & High & High & - \\
\hline & High & High & High & Low & - \\
\hline & High & High & Low & High & - \\
\hline & High & Low & High & High & - \\
\hline & Low & High & High & High & - \\
\hline (3) & High & High & High & High & - \\
\hline (4) & Low & Low & Low & - & High \\
\hline \multirow[t]{14}{*}{ (5) } & High & Low & Low & - & High \\
\hline & Low & High & Low & - & High \\
\hline & Low & Low & High & - & High \\
\hline & Low & Low & Low & - & Low \\
\hline & High & High & Low & - & High \\
\hline & High & Low & High & - & High \\
\hline & High & Low & Low & - & Low \\
\hline & Low & High & High & - & High \\
\hline & Low & High & Low & - & Low \\
\hline & Low & Low & High & - & Low \\
\hline & High & High & High & - & High \\
\hline & High & High & Low & - & Low \\
\hline & High & Low & High & - & Low \\
\hline & Low & High & High & - & Low \\
\hline (6) & High & High & High & - & Low \\
\hline (7) & Low & Low & - & Low & High \\
\hline \multirow[t]{14}{*}{ (8) } & High & Low & - & Low & High \\
\hline & Low & High & - & Low & High \\
\hline & Low & Low & - & High & High \\
\hline & Low & Low & - & Low & Low \\
\hline & High & High & - & Low & High \\
\hline & High & Low & - & High & High \\
\hline & High & Low & - & Low & Low \\
\hline & Low & High & - & High & High \\
\hline & Low & High & - & Low & Low \\
\hline & Low & Low & - & High & Low \\
\hline & High & High & - & High & High \\
\hline & High & High & - & Low & Low \\
\hline & High & Low & - & High & Low \\
\hline & Low & High & - & High & Low \\
\hline (9) & High & High & - & High & Low \\
\hline (10) & Low & - & Low & Low & High \\
\hline (11) & High & - & Low & Low & High \\
\hline
\end{tabular}


Table IV. Continued.

\begin{tabular}{|c|c|c|c|c|c|}
\hline \multirow[b]{2}{*}{ Group } & \multicolumn{5}{|c|}{ Composition } \\
\hline & STAT1 & STAT3 & STAT4 & STAT5B & STAT6 \\
\hline & Low & - & High & Low & High \\
\hline & Low & - & Low & High & High \\
\hline & Low & - & Low & Low & Low \\
\hline & High & - & High & Low & High \\
\hline & High & - & Low & High & High \\
\hline & High & - & Low & Low & Low \\
\hline & Low & - & High & High & High \\
\hline & Low & - & High & Low & Low \\
\hline & Low & - & Low & High & Low \\
\hline & High & - & High & High & High \\
\hline & High & - & High & Low & Low \\
\hline & High & - & Low & High & Low \\
\hline & Low & - & High & High & Low \\
\hline (12) & High & - & High & High & Low \\
\hline (13) & - & Low & Low & Low & High \\
\hline \multirow[t]{14}{*}{ (14) } & - & High & Low & Low & High \\
\hline & - & Low & High & Low & High \\
\hline & - & Low & Low & High & High \\
\hline & - & Low & Low & Low & Low \\
\hline & - & High & High & Low & High \\
\hline & - & High & Low & High & High \\
\hline & - & High & Low & Low & Low \\
\hline & - & Low & High & High & High \\
\hline & - & Low & High & Low & Low \\
\hline & - & Low & Low & High & Low \\
\hline & - & High & High & High & High \\
\hline & - & High & High & Low & Low \\
\hline & - & High & Low & High & Low \\
\hline & - & Low & High & High & Low \\
\hline (15) & - & High & High & High & Low \\
\hline
\end{tabular}

'-', gene not selected. Bold, favorable prognosis groups in univariate survival analysis. STAT, signal transducer and activator of transcription.

However, studies that explored the association between the prognosis of melanoma and the JAK-STAT signaling pathway are limited. In the present study, the expression of $J A K$ and STAT family genes in melanoma was investigated based on TCGA data. The observation that JAK-STAT gene expression is associated with the MAPK signaling pathway is in agreement with a previous study, which demonstrated that the JAK-STAT signaling pathway is integrated with the MAPK signaling pathway (33-35) and is associated with melanoma (36). Expression of JAK2, JAK3, TYK2, STAT2 and $S T A T 5 B$ was not observed after normalizing mRNA expression in the present study, suggesting that these genes were expressed at a low level. High expression of STAT1, STAT3, STAT4 and STAT5B, as well as low expression of STAT6, were associated with a favorable prognosis of patients with SKCM. These results are consistent with other studies, in which high
Table V. Grouping information for joint effects analysis of three selected STAT genes.

\begin{tabular}{|c|c|c|c|c|c|}
\hline \multirow[b]{2}{*}{ Group } & \multicolumn{5}{|c|}{ Composition } \\
\hline & STATI & STAT3 & STAT4 & STAT5B & STAT6 \\
\hline $\mathrm{i}$ & Low & Low & Low & - & - \\
\hline \multirow[t]{6}{*}{ ii } & High & Low & Low & - & - \\
\hline & Low & High & Low & - & - \\
\hline & Low & Low & High & - & - \\
\hline & High & High & Low & - & - \\
\hline & High & Low & High & - & - \\
\hline & Low & High & High & - & - \\
\hline iii & High & High & High & - & - \\
\hline iv & Low & Low & - & Low & - \\
\hline \multirow[t]{6}{*}{$\mathrm{v}$} & Low & Low & - & Low & - \\
\hline & High & High & - & Low & - \\
\hline & High & High & - & High & - \\
\hline & Low & High & - & Low & - \\
\hline & Low & Low & - & High & - \\
\hline & High & High & - & High & - \\
\hline vi & High & High & - & High & - \\
\hline vii & Low & Low & - & - & High \\
\hline \multirow[t]{6}{*}{ viii } & High & Low & - & - & High \\
\hline & Low & High & - & - & High \\
\hline & Low & Low & - & - & Low \\
\hline & High & High & - & - & High \\
\hline & High & Low & - & - & Low \\
\hline & Low & High & - & - & Low \\
\hline ix & High & High & - & - & Low \\
\hline $\mathrm{x}$ & Low & - & Low & Low & - \\
\hline \multirow[t]{6}{*}{$\mathrm{xi}$} & High & - & Low & Low & - \\
\hline & Low & - & High & Low & - \\
\hline & Low & - & Low & High & - \\
\hline & High & - & High & Low & - \\
\hline & High & - & Low & High & - \\
\hline & Low & - & High & High & - \\
\hline xii & High & - & High & High & - \\
\hline xiii & Low & - & Low & - & High \\
\hline \multirow[t]{6}{*}{ xiv } & High & - & Low & - & High \\
\hline & Low & - & High & - & High \\
\hline & Low & - & Low & - & Low \\
\hline & High & - & High & - & High \\
\hline & High & - & Low & - & Low \\
\hline & Low & - & High & - & Low \\
\hline $\mathrm{xv}$ & High & - & High & - & Low \\
\hline xvi & Low & - & - & Low & High \\
\hline \multirow[t]{6}{*}{ xvii } & High & - & - & Low & High \\
\hline & Low & - & - & High & High \\
\hline & Low & - & - & Low & Low \\
\hline & High & - & - & High & High \\
\hline & High & - & - & Low & Low \\
\hline & Low & - & - & High & Low \\
\hline xviii & High & - & - & High & Low \\
\hline xiv & - & Low & Low & Low & - \\
\hline $\mathrm{xx}$ & - & High & Low & Low & - \\
\hline
\end{tabular}


Table V. Continued.

\begin{tabular}{|c|c|c|c|c|c|}
\hline \multirow[b]{2}{*}{ Group } & \multicolumn{5}{|c|}{ Composition } \\
\hline & STATl & STAT3 & STAT4 & STAT5B & STAT6 \\
\hline & - & Low & High & High & - \\
\hline & - & Low & Low & Low & - \\
\hline & - & High & High & High & - \\
\hline & - & High & Low & Low & - \\
\hline & - & Low & High & High & - \\
\hline$x x i$ & - & High & High & High & - \\
\hline xxii & - & Low & Low & - & High \\
\hline \multirow[t]{6}{*}{ xxiii } & - & High & Low & - & High \\
\hline & - & Low & High & - & High \\
\hline & - & Low & Low & - & Low \\
\hline & - & High & High & - & High \\
\hline & - & High & Low & - & Low \\
\hline & - & Low & High & - & Low \\
\hline xxiv & - & High & High & - & Low \\
\hline$x x v$ & - & Low & - & Low & High \\
\hline \multirow[t]{6}{*}{ xxvi } & - & High & - & High & High \\
\hline & - & Low & - & Low & High \\
\hline & - & Low & - & Low & Low \\
\hline & - & High & - & High & High \\
\hline & - & High & - & High & Low \\
\hline & - & Low & - & Low & Low \\
\hline xxvii & - & High & - & High & Low \\
\hline xxviii & - & - & Low & Low & High \\
\hline \multirow[t]{6}{*}{ xxix } & - & - & High & High & High \\
\hline & - & - & Low & Low & High \\
\hline & - & - & Low & Low & Low \\
\hline & - & - & High & High & High \\
\hline & - & - & High & High & Low \\
\hline & - & - & Low & Low & Low \\
\hline $\mathrm{xxx}$ & - & - & High & High & Low \\
\hline
\end{tabular}

'-', gene not selected. Bold, favorable prognosis groups in univariate survival analysis. STAT, signal transducer and activator of transcription.

expression of STAT1 was associated with favorable prognosis in high-grade serous ovarian cancer (HGSC) (37), colorectal cancer (38) and esophageal squamous cell carcinoma (39). In addition, high expression of STATI in HGSC was significantly associated with the recruitment of intraepithelial $\mathrm{CD} 8^{+} \mathrm{T}$ cells, which enhanced the prognostic and predictive value of intratumoral $\mathrm{CD}^{+} \mathrm{T}$ cells in HGSC (40), potentially due to tumors with high STATI mRNA expression exhibiting elevated expression of genes specific for tumor-associated macrophages and immunosuppressive $\mathrm{T}$ lymphocytes (7). The results of the enrichment analysis in the present study also revealed that STAT1 was associated with the immune response, which suggested that $S T A T 1$ may accelerate the immune cell response to cancer (41). However, high STAT1 expression was associated with poor prognosis in glioblastoma $(42)$, and breast $(7,8)$, ovarian, lung, blood and brain (9) cancer.
Table VI. Grouping information for joint effects analysis of two selected STAT genes

\begin{tabular}{|c|c|c|c|c|c|}
\hline \multirow[b]{2}{*}{ Group } & \multicolumn{5}{|c|}{ Composition } \\
\hline & STAT1 & STAT3 & STAT4 & STAT5B & STAT6 \\
\hline I & Low & Low & - & - & - \\
\hline \multirow[t]{2}{*}{ II } & High & Low & - & - & - \\
\hline & Low & High & - & - & - \\
\hline III & High & High & - & - & - \\
\hline IV & Low & - & Low & - & - \\
\hline \multirow[t]{2}{*}{ V } & High & - & Low & - & - \\
\hline & Low & - & High & - & - \\
\hline VI & High & - & High & - & - \\
\hline VII & Low & - & - & Low & - \\
\hline \multirow[t]{2}{*}{ VIII } & Low & - & - & High & - \\
\hline & High & - & - & Low & - \\
\hline IX & High & - & - & High & - \\
\hline$X$ & Low & - & - & - & High \\
\hline \multirow[t]{2}{*}{ XI } & Low & - & - & - & Low \\
\hline & High & - & - & - & High \\
\hline XII & High & - & - & - & Low \\
\hline XIII & - & Low & Low & - & - \\
\hline \multirow[t]{2}{*}{ XIV } & - & High & Low & - & - \\
\hline & - & Low & High & - & - \\
\hline XV & - & High & High & - & - \\
\hline XVI & - & Low & - & Low & - \\
\hline \multirow[t]{2}{*}{ XVII } & - & Low & - & High & - \\
\hline & - & High & - & Low & - \\
\hline XVIII & - & High & - & High & - \\
\hline XIX & - & Low & - & - & High \\
\hline \multirow[t]{2}{*}{$\mathrm{XX}$} & - & Low & - & - & Low \\
\hline & - & High & - & - & High \\
\hline XXI & - & High & - & - & Low \\
\hline XXII & - & - & Low & Low & - \\
\hline \multirow[t]{2}{*}{ XXIII } & - & - & Low & High & - \\
\hline & - & - & High & Low & - \\
\hline XXIV & - & - & High & High & - \\
\hline XXV & - & - & Low & - & High \\
\hline \multirow[t]{2}{*}{ XXVI } & - & - & Low & - & Low \\
\hline & - & - & High & - & High \\
\hline XXVII & - & - & High & - & Low \\
\hline XXVIII & - & - & - & Low & High \\
\hline \multirow[t]{2}{*}{ XXIV } & - & - & - & Low & Low \\
\hline & - & - & - & High & High \\
\hline XXX & - & - & - & High & Low \\
\hline
\end{tabular}

'-', gene not selected. Bold, favorable prognosis groups in univariate survival analysis. STAT, signal transducer and activator of transcription.

In contrast to that of STAT1, STAT3 expression is downregulated in malignant pleural mesothelioma (43); however, the prognostic value of this association has not been reported. The majority of studies on STAT3 and cancer prognosis have 

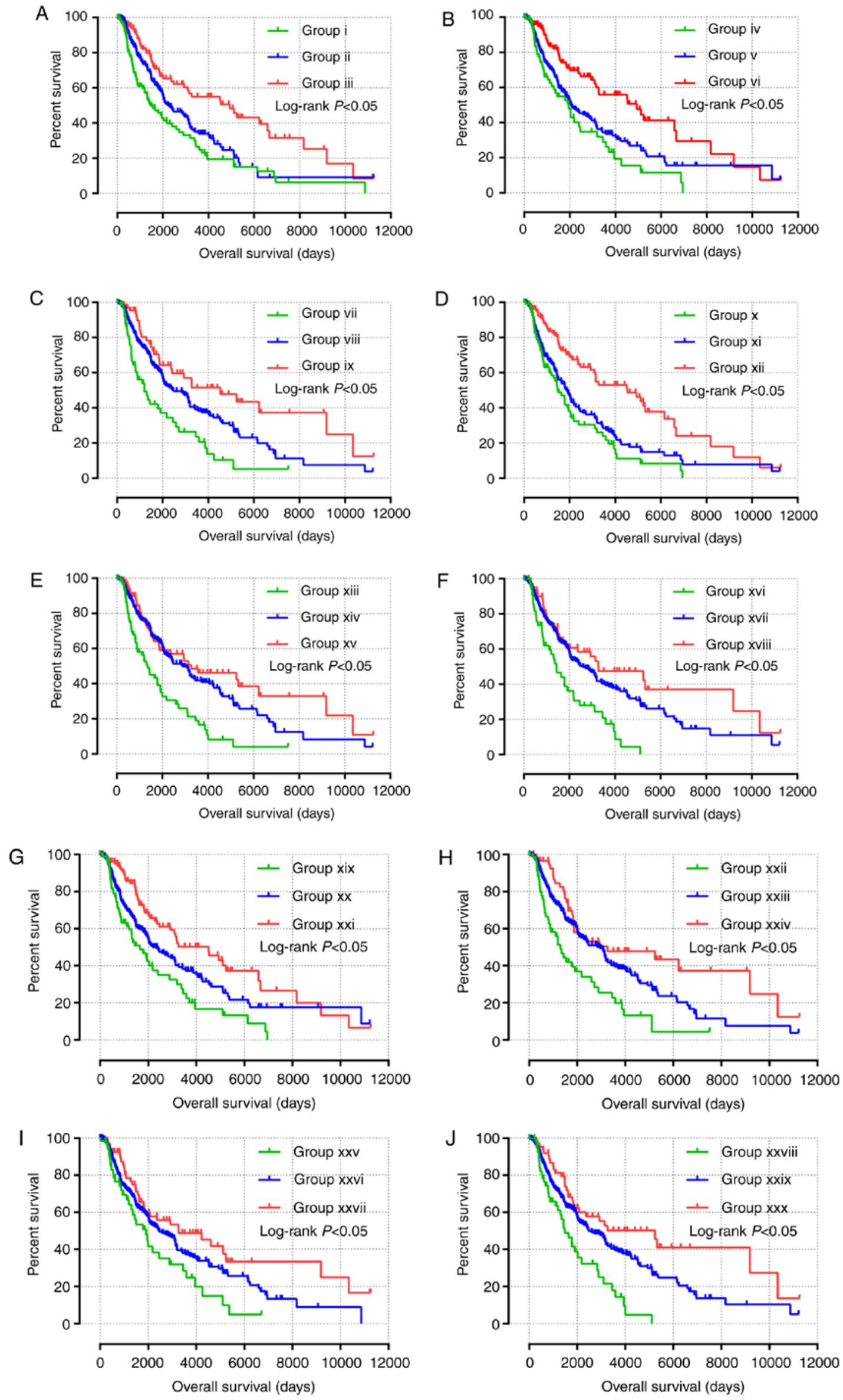

Figure 6. (A-J) Joint effects analysis of the effects of combined expression of three selected genes on overall survival in patients with skin cutaneous melanoma according to (A) group i-iii, (B) group iv-vi, (C) group vi-ix, (D) group x-xii, (E) group xiii-xv, (F) group xvi-xvii, (G) group xix-xxi, (H) group xxii-xxiv, (I) group xxv-xxvii and (J) group xxviii-xxx. 
Table VII. Joint effects analysis of the prognostic value of combinations of gene expression in skin cutaneous melanoma.

\begin{tabular}{|c|c|c|c|c|c|c|}
\hline Group & $\begin{array}{l}\text { No. of } \\
\text { genes }\end{array}$ & $\begin{array}{l}\text { Patients } \\
(\mathrm{n}=458)\end{array}$ & No. of events (\%) & MST (days) & $\begin{array}{l}\text { Log-rank } \\
\text { P-value }\end{array}$ & $\mathrm{HR}(95 \% \mathrm{CI})$ \\
\hline 1 & 5 & 38 & $24(63.1)$ & 1,301 & Ref. & Ref. \\
\hline 2 & 5 & 87 & $46(52.9)$ & 2,030 & 0.073 & $0.636(0.487-1.043)$ \\
\hline 3 & 5 & 106 & $53(50.0)$ & 1,766 & 0.094 & $0.661(0.407-1.073)$ \\
\hline 4 & 5 & 98 & $37(37.8)$ & 3,196 & $<0.001^{\mathrm{a}}$ & $0.352(0.210-0.590)$ \\
\hline 5 & 5 & 93 & $42(45.2)$ & 4,533 & $<0.001^{\mathrm{a}}$ & $0.322(0.194-0.535)$ \\
\hline 6 & 5 & 36 & $17(47.2)$ & 3,259 & $<0.001^{\mathrm{a}}$ & $0.280(0.149-0.528)$ \\
\hline (1) & 4 & 71 & $42(59.2)$ & 1,441 & Ref. & Ref. \\
\hline (2) & 4 & 301 & $140(46.4)$ & 2,192 & $0.014^{\mathrm{a}}$ & $0.648(0.458-0.915)$ \\
\hline (3) & 4 & 86 & $37(43.0)$ & 4,930 & $<0.001^{\mathrm{a}}$ & $0.376(0.241-0588)$ \\
\hline (4) & 4 & 61 & $37(60.7)$ & 1,197 & Ref. & Ref. \\
\hline (5) & 4 & 351 & $160(45.6)$ & 2,829 & $<0.001^{\mathrm{a}}$ & $0.515(0.360-0.738)$ \\
\hline (6) & 4 & 46 & $22(47.8)$ & 5,237 & $<0.001^{\mathrm{a}}$ & $0.312(0.182-0.535)$ \\
\hline (7) & 4 & 47 & $27(57.4)$ & 1,354 & Ref. & Ref. \\
\hline (8) & 4 & 365 & $171(46.8)$ & 2,470 & $0.002^{\mathrm{a}}$ & $0.530(0.352-0.798)$ \\
\hline (9) & 4 & 46 & $21(45.7)$ & 3,266 & $<0.001^{\mathrm{a}}$ & $0.370(0.189-0.601)$ \\
\hline (10) & 4 & 56 & $34(60.7)$ & 1,354 & Ref. & Ref. \\
\hline (11) & 4 & 351 & $160(45.6)$ & 2,588 & $<0.001^{\mathrm{a}}$ & $0.484(0.333-0.704)$ \\
\hline (12) & 4 & 51 & $25(49.0)$ & 3,259 & $<0.001^{\mathrm{a}}$ & $0.338(0.200-0.573)$ \\
\hline (13) & 4 & 42 & $26(61.9)$ & 1,354 & Ref. & Ref. \\
\hline (14) & 4 & 372 & $171(46.0)$ & 2,588 & $0.001^{\mathrm{a}}$ & $0.498(0.328-0.755)$ \\
\hline (15) & 4 & 44 & $22(50.0)$ & 2,927 & $<0.001^{\mathrm{a}}$ & $0.344(0.193-0.612)$ \\
\hline $\mathrm{i}$ & 3 & 130 & $75(57.7)$ & 1,441 & Ref. & Ref. \\
\hline ii & 3 & 250 & $112(44.8)$ & 2,273 & $0.022^{\mathrm{a}}$ & $0.710(0.529-0.952)$ \\
\hline iii & 3 & 103 & $46(44.7)$ & 4,930 & $<0.001^{\mathrm{a}}$ & $0.418(0.289-0.605)$ \\
\hline iv & 3 & 91 & $47(51.6)$ & 1,949 & Ref. & Ref. \\
\hline $\mathrm{v}$ & 3 & 267 & $131(49.1)$ & 2,071 & 0.086 & $0.746(0.534-1.042)$ \\
\hline vi & 3 & 125 & $51(40.8)$ & 4,930 & $<0.001^{\mathrm{a}}$ & $0.415(0.278-0.620)$ \\
\hline vii & 3 & 78 & $44(56.4)$ & 1,197 & Ref. & Ref. \\
\hline viii & 3 & 312 & $146(46.8)$ & 2,470 & $<0.001^{\mathrm{a}}$ & $0.530(0.377-0.744)$ \\
\hline ix & 3 & 93 & $39(41.9)$ & 4,526 & $<0.001^{\mathrm{a}}$ & $0.328(0.212-0.508)$ \\
\hline $\mathrm{x}$ & 3 & 103 & $61(59.2)$ & 1,487 & Ref. & Ref. \\
\hline $\mathrm{xi}$ & 3 & 245 & $127(51.8)$ & 1,864 & 0.127 & $0.788(0.580-1.070)$ \\
\hline xii & 3 & 135 & $60(44.4)$ & 4,533 & $<0.001^{\mathrm{a}}$ & $0.388(0.270-0.557)$ \\
\hline xiii & 3 & 95 & $55(57.9)$ & 1,354 & Ref. & Ref. \\
\hline xiv & 3 & 276 & $152(551)$ & 2,889 & $<0.001^{\mathrm{a}}$ & $0.480(0.348-0.661)$ \\
\hline $\mathrm{xv}$ & 3 & 112 & $50(44.6)$ & 3,259 & $<0.001^{\mathrm{a}}$ & $0.367(0.249-0.542)$ \\
\hline xvi & 3 & 69 & $40(58.0)$ & 1,429 & Ref. & Ref. \\
\hline xvii & 3 & 324 & $148(45.7)$ & 2,588 & $<0.001^{\mathrm{a}}$ & $0.502(0.352-0.715)$ \\
\hline xviii & 3 & 90 & $40(44.4)$ & 3,266 & $<0.001^{\mathrm{a}}$ & $0.358(0.229-0.559)$ \\
\hline xix & 3 & 87 & $51(58.6)$ & 1,655 & Ref. & Ref. \\
\hline $\mathrm{xx}$ & 3 & 268 & $121(45.1)$ & 2,367 & $0.012^{\mathrm{a}}$ & $0.658(0.474-0.913)$ \\
\hline xxi & 3 & 128 & $57(44.5)$ & 4,507 & $<0.001^{\mathrm{a}}$ & $0.419(0.286-0.613)$ \\
\hline xxii & 3 & 70 & $43(61.4)$ & 1,301 & Ref. & Ref. \\
\hline xxiii & 3 & 328 & $148(45.1)$ & 2,948 & $<0.001^{\mathrm{a}}$ & $0.530(0.377-0.745)$ \\
\hline xxiv & 3 & 85 & $38(44.7)$ & 3,259 & $<0.001^{\mathrm{a}}$ & $0.348(0.223-0.542)$ \\
\hline $\mathrm{xxv}$ & 3 & 66 & $35(53.0)$ & 1,910 & Ref. & Ref. \\
\hline xxvi & 3 & 323 & $150(46.4)$ & 2,470 & $0.043^{\mathrm{a}}$ & $0.683(0.472-0.988)$ \\
\hline xxvii & 3 & 94 & $44(46.8)$ & 3,266 & $0.001^{\mathrm{a}}$ & $0.462(0.294-0.724)$ \\
\hline xxviii & 3 & 70 & $40(57.1)$ & 1,486 & Ref. & Ref. \\
\hline xxix & 3 & 323 & $149(46.1)$ & 2,470 & $0.001^{\mathrm{a}}$ & $0.536(0.376-0.764)$ \\
\hline $\mathrm{xxx}$ & 3 & 90 & $40(44.4)$ & 5,237 & $<0.001^{\mathrm{a}}$ & $0.349(0.223-0.545)$ \\
\hline
\end{tabular}


Table VII. Continued.

\begin{tabular}{|c|c|c|c|c|c|c|}
\hline Group & $\begin{array}{c}\text { No. of } \\
\text { genes }\end{array}$ & $\begin{array}{l}\text { Patients } \\
(n=458)\end{array}$ & No. of events (\%) & MST (days) & $\begin{array}{l}\text { Log-rank } \\
\text { P-value }\end{array}$ & $\mathrm{HR}(95 \% \mathrm{CI})$ \\
\hline I & 2 & 139 & $70(50.4)$ & 1,949 & Ref. & Ref. \\
\hline II & 2 & 180 & $92(51.1)$ & 2,005 & 0.519 & $0.902(0.660-1.233)$ \\
\hline III & 2 & 164 & $67(40.9)$ & 4,526 & $<0.001^{\mathrm{a}}$ & $0.485(0.346-0.678)$ \\
\hline IV & 2 & 168 & $96(57.1)$ & 1,487 & Ref. & Ref. \\
\hline $\mathrm{V}$ & 2 & 122 & $48(39.3)$ & 2,454 & $0.017^{\mathrm{a}}$ & $0.655(0.462-0.928)$ \\
\hline VI & 2 & 193 & $85(44.0)$ & 3,564 & $<0.001^{\mathrm{a}}$ & $0.477(0.356-0.641)$ \\
\hline VII & 2 & 133 & $70(52.6)$ & 1,780 & Ref. & Ref. \\
\hline VIII & 2 & 192 & $90(46.9)$ & 2,273 & $0.008^{\mathrm{a}}$ & $0.654(0.477-0.897)$ \\
\hline IX & 2 & 133 & $59(44.4)$ & 4,507 & $<0.001^{\mathrm{a}}$ & $0.449(0.316-0.638)$ \\
\hline $\mathrm{X}$ & 2 & 125 & $70(56.0)$ & 1,438 & Ref. & Ref. \\
\hline XI & 2 & 208 & $94(45.2)$ & 3,080 & $<0.001^{\mathrm{a}}$ & $0.483(0.353-0.662)$ \\
\hline XII & 2 & 125 & $55(44.0)$ & 3,259 & $<0.001^{\mathrm{a}}$ & $0.435(0.304-0.623)$ \\
\hline XIII & 2 & 130 & $75(57.7)$ & 1,441 & Ref. & Ref. \\
\hline XIV & 2 & 198 & $84(42.4)$ & 2,545 & $0.011^{\mathrm{a}}$ & $0.677(0.488-0.912)$ \\
\hline XV & 2 & 130 & $60(46.2)$ & 3,259 & $<0.001^{\mathrm{a}}$ & $0.466(0.332-0.656)$ \\
\hline XVI & 2 & 148 & $72(48.6)$ & 1,992 & Ref. & Ref. \\
\hline XVII & 2 & 162 & $80(49.4)$ & 2,071 & 0.297 & $0.843(0.612-1.162)$ \\
\hline XVIII & 2 & 148 & $67(45.3)$ & 3,259 & $0.001^{\mathrm{a}}$ & $0.564(0.403-0.791)$ \\
\hline XIX & 2 & 111 & $61(54.9)$ & 1,910 & Ref. & Ref. \\
\hline $\mathrm{XX}$ & 2 & 236 & $106(44.9)$ & 3,080 & $0.008^{\mathrm{a}}$ & $0.652(0.476-0.894)$ \\
\hline XXI & 2 & 111 & $52(46.8)$ & 3,259 & $<0.001^{\mathrm{a}}$ & $0.508(0.349-0.739)$ \\
\hline XXII & 2 & 141 & $77(54.6)$ & 1,780 & Ref. & Ref. \\
\hline XXIII & 2 & 176 & $78(44.3)$ & 2,192 & $0.015^{\mathrm{a}}$ & $0.674(0.490-0.926)$ \\
\hline XXIV & 2 & 141 & $64(45.4)$ & 3,259 & $<0.001^{\mathrm{a}}$ & $0.466(0.333-0.653)$ \\
\hline XXV & 2 & 118 & $65(55.1)$ & 1,544 & Ref. & Ref. \\
\hline XXVI & 2 & 222 & $106(47.4)$ & 3,136 & $<0.001^{\mathrm{a}}$ & $0.548(0.400-0.750)$ \\
\hline XXVII & 2 & 118 & $48(40.7)$ & 3,259 & $<0.001^{\mathrm{a}}$ & $0.399(0.273-0.583)$ \\
\hline XXVIII & 2 & 105 & $56(53.3)$ & 1,780 & Ref. & Ref. \\
\hline XXIX & 2 & 248 & $114(46.0)$ & 2,470 & $0.013^{\mathrm{a}}$ & $0.667(0.484-0.920)$ \\
\hline $\mathrm{XXX}$ & 2 & 105 & $49(46.7)$ & 3,424 & $<0.001^{\mathrm{a}}$ & $0.466(0.314-0.692)$ \\
\hline
\end{tabular}

${ }^{\text {aP }}<0.05$. MST, median survival time; HR, hazard ratio; CI, confidence interval; Ref., reference.

demonstrated that phosphorylated STAT3 is associated with a poor outcome in colorectal cancer (10), multiple myeloma (44) and urothelial carcinoma (45). In addition, STAT4 has been detected in several types of cancer, including prostate (46), breast (47), gastric (48) and ovarian (49) cancer. The upregulation of STAT4 in hepatocellular carcinoma is associated with favorable prognosis, possibly due to the expression of STAT4 in the immune cells; however, the function and mechanism of STAT4 in non-immune cells remains unknown (50). High expression of $S T A T 5 B$ in astrocytoma is associated with poor prognosis (51), whereas high expression of STAT6 is associated with poor prognosis in colon cancer (52).

The potential effects of these associations require further exploration. For instance, colorectal carcinoma cell lines exhibiting low STAT1 and high STAT3 expression levels are associated with enhanced tumor growth in xenografts; by contrast, xenograft cell lines with high STAT1 and low STAT3 levels grew slowly (53). Thus, gene interactions may influence the cancer outcome. The different expression level of these two genes in different types of cancer may serve different roles. Joint effects analysis in the present study suggested that any combination of the tested markers may have a higher prognostic value compared with that of any individual biomarker.

The STAT gene family affects cell differentiation (54), invasion (55-57), adhesion (58) and migration (59), as well as cell cycle $(60-62)$ and colony formation $(39,63)$ through the JAK-STAT signaling pathway; these processes are associated with the occurrence, development and outcome of cancer. The potential mechanism of how these genes affect prognosis should be further studied.

The present study investigated the prognostic value of the key genes in the JAK-STAT signaling pathway; only STAT genes were demonstrated to affect the prognosis of SKCM. In melanoma research, no golden standard exists for diagnosis or prognosis that would serve a similar role as the hairy-related 2 gene in breast cancer or prostate specific antigen in prostate 

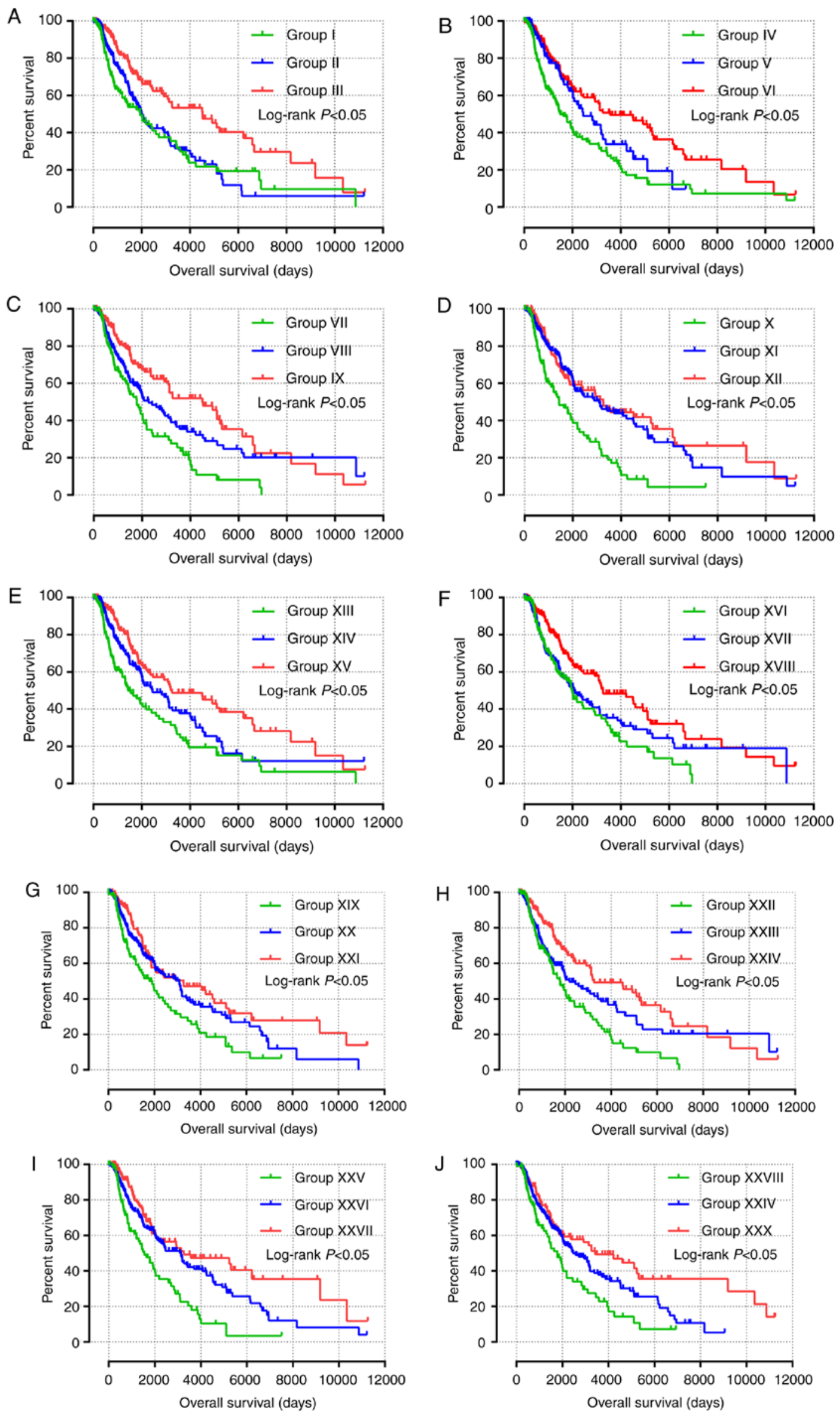

Figure 7. (A-J) Joint effects analysis of the influence of combined expression of two selected genes on overall survival in patients with skin cutaneous melanoma according to (A) group I-III, (B) group IV-VI, (C) group VI-IX, (D) group X-XII, (E) group XIII-XV, (F) group XVI-XVII, (G) group XIX-XXI, (H) group XXII-XXIV, (I) group XXV-XXVII and (J) group XXVIII-XXX. 
A

Enrichment plot:

GO_NEGATIVE_REGULATION_OF_ADAPTIVE_IMMUNE RESPONSE

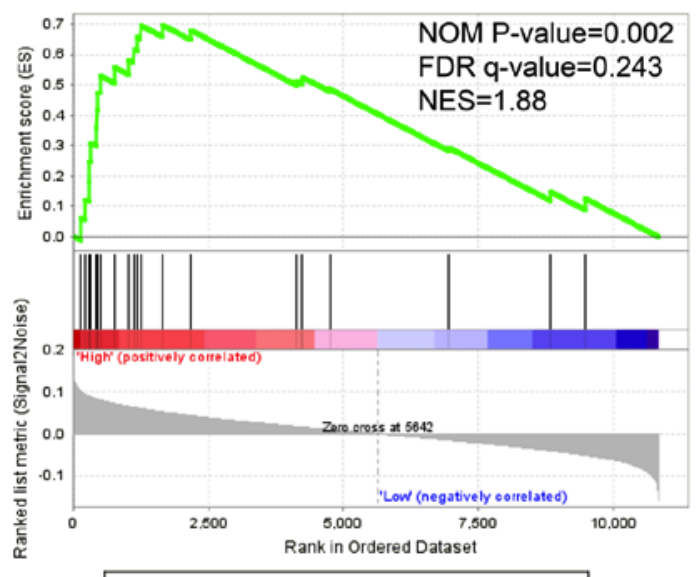

C

-Enrichment profile - Hits - - Ranking metric scores

Enrichment plot:

GO_REGULATION_OF_CD4_POSITIVE_ALPHA_BETA_T_ CELL_ACTIVATION

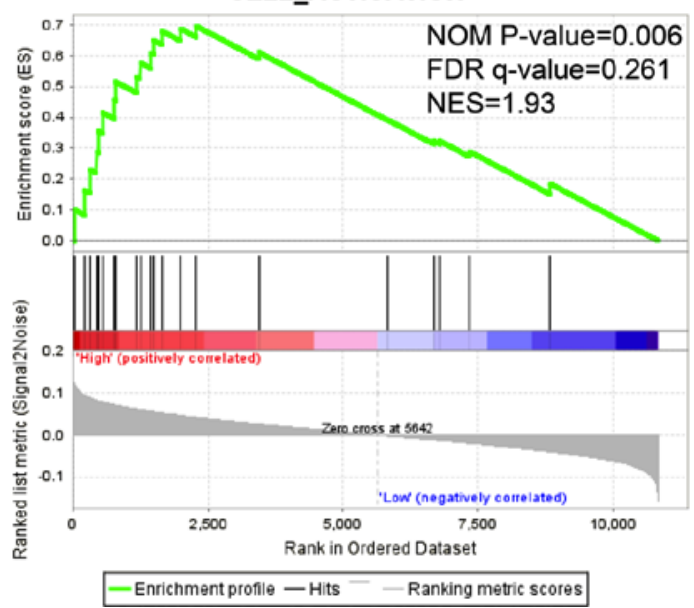

E

Enrichment plot: GO_WNT_PROTEIN_BINDING

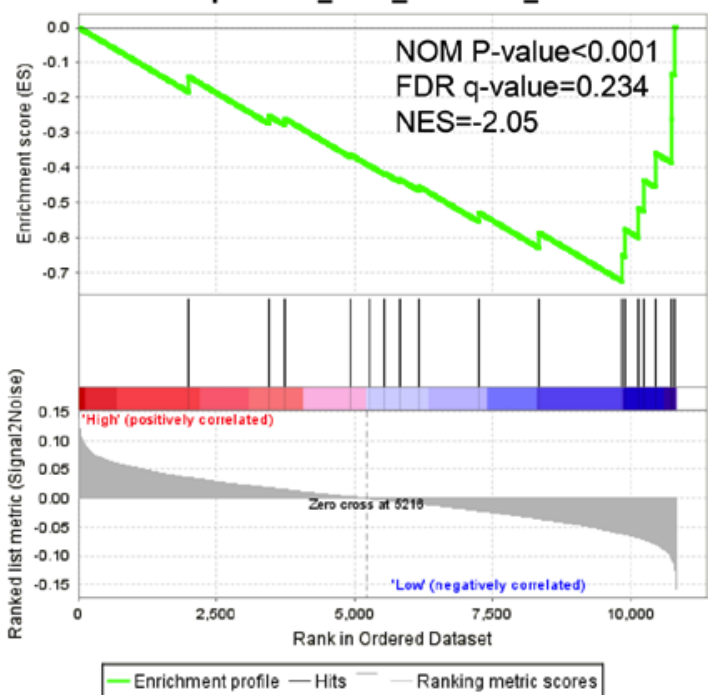

B

Enrichment plot:
GO_POSITIVE_REGULATION_OF_CELL_CELL_ADHESIO

N

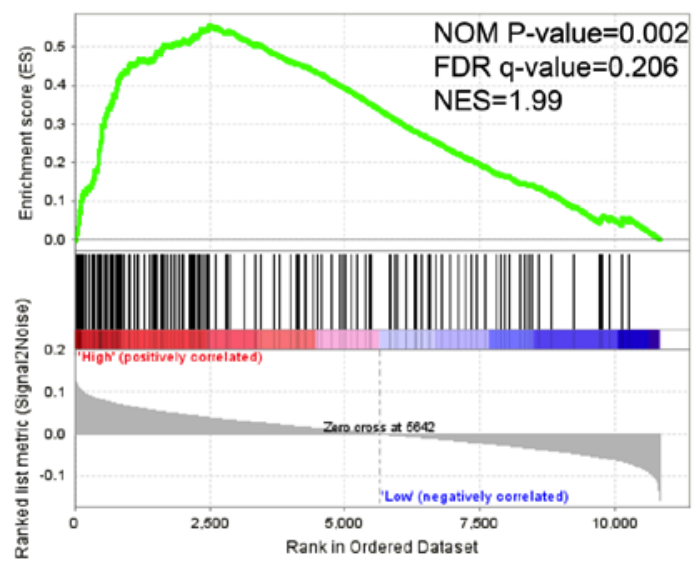

-Enrichment profile - Hits - - Ranking metric scores

D

Enrichment plot:

GO_REGULATION_OF_CELL_CELL_ADHESION

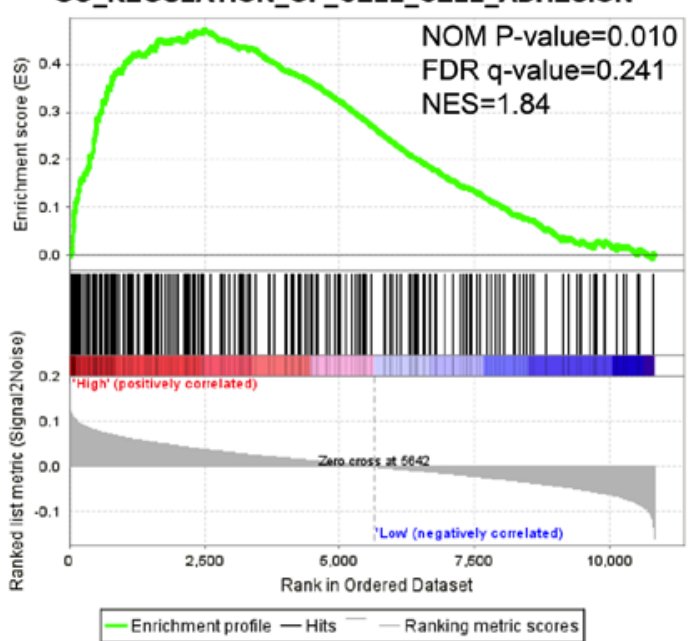

$\mathrm{F}$

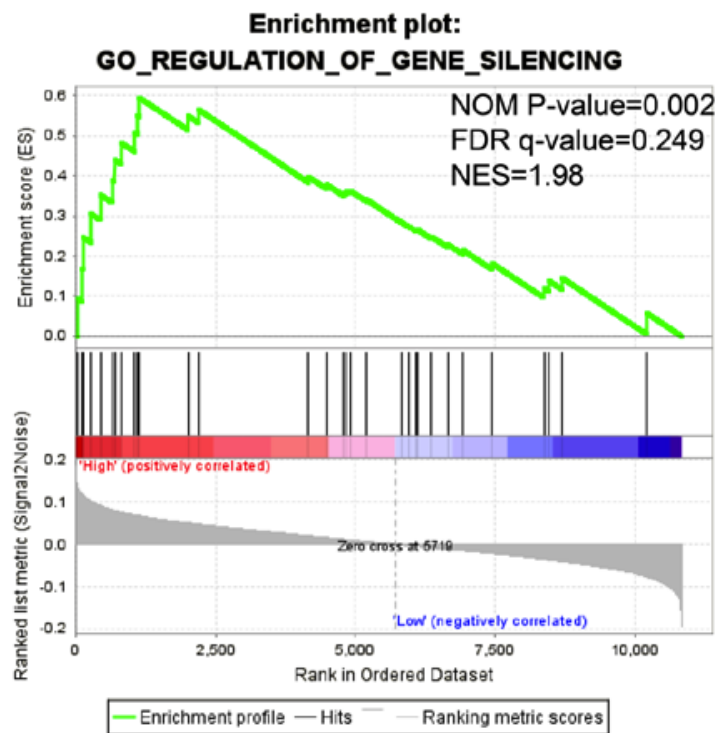

Figure 8. GSEA of genes expressed in patients with skin cutaneous melanoma. (A-D) GSEA of the c5 reference gene sets for the high STAT1 expression group. (A) $\mathrm{c} 5$ item negative regulation of adaptive immune response, (B) $\mathrm{c} 5$ item positive regulation of cell-cell adhesion, (C) $\mathrm{c} 5$ item regulation of CD4 positive alpha beta T cell activation and (D) c5 item regulation of cell-cell adhesion. (E) GSEA of the c5 reference gene sets for the low STAT4 expression group. (F) GSEA of the c5 reference gene sets for the high STAT5B expression group. STAT, signal transducer and activator of transcription; GSEA, gene set enrichment analysis; NES, normalized enrichment score; FDR, false discovery rate; NOM, nominal. 
cancer. Certain genes may act as biomarkers to predict the prognosis and mechanism of SKCM, including RAF (Raf proto-oncogene), MEK (MAP/ERK kinase), MAPK, RAS, myelocytomatosis oncogene and S100 calcium binding protein (64-69). However, further research is required to identify a golden standard for predicting melanoma.

There were certain limitations in the present study. Firstly, only $J A K$ expression data were reported following normalization; additional mRNA expression data are needed to further confirm these observations. Secondly, this is an association study. Further research is needed to explore the function and mechanism of the genes of the JAK-STAT signaling pathway identified in the present study in patients with SKCM. Another limitation of the current study is the limited sample size. Improved design and larger sample size studies are necessary to validate these results. Finally, there were no expression standards to measure whether the gene expression was high or low.

To the best of our knowledge, the present study is the first to evaluate the association between the expression of genes of the JAK-STAT signaling pathway and OS in patients with SKCM, and to identify the joint effects of prognostic values among the five identified genes. Overall, the results of the present study provided a novel insight into the function of these genes in SKCM clinical outcomes, and may be further utilized in the clinic for predicting the prognosis of SKCM.

In conclusion, the combination of the highly expressed STAT1, STAT3, STAT4 and STAT5B genes, and the lowly expressed STAT6 gene is associated with a favorable prognosis in patients with SKCM, and may be used as a novel biomarker for predicting the prognosis of patients with SKCM. The expression of the genes in the STAT family may affect the prognosis of SKCM by accelerating the immune response and immune cell activity, and by involving the MAPK signaling pathway. Further studies are required to validate these findings.

\section{Acknowledgements}

Not applicable.

\section{Funding}

The present study was funded by the National Nature Science Foundation of China (grant no. 81760344).

\section{Availability of data and materials}

The datasets generated and/or analyzed during the current study are available in the TCGA repository, https://portal.gdc.cancer.gov/.

\section{Authors' contributions}

XZ and FP conceived and designed the study. QW, HM and SL processed the data and performed the statistical analysis. LZ, $\mathrm{RH}, \mathrm{XW}$ and XL wrote and revised the manuscript and helped to perform the analysis and interpretation of data. All authors read and approved the final version of the manuscript.

\section{Ethics approval and consent to participate}

The present study did not involve human or animal subjects.

\section{Patient consent for publication}

Not applicable.

\section{Competing interests}

The authors declare that they have no competing interests.

\section{References}

1. Goldstein BG and Goldstein AO: Diagnosis and management of malignant melanoma. Am Fam Physician 63: 1359-1368, 2001

2. Situm M, Buljan M, Kolić M and Vučić M: Melanoma-clinical, dermatoscopical, and histopathological morphological characteristics. Acta Dermatovenerol Croat 22: 1-12, 2014.

3. Grimaldi AM, Simeone E and Ascierto PA: The role of MEK inhibitors in the treatment of metastatic melanoma. Curr Opin Oncol 26: 196-203, 2014.

4. Ferlay J, Soerjomataram I, Dikshit R, Eser S, Mathers C, Rebelo M, Parkin DM, Forman D and Bray F: Cancer incidence and mortality worldwide: Sources, methods and major patterns in GLOBOCAN 2012. Int J Cancer 136: E359-E386, 2015.

5. Siegel RL, Miller KD and Jemal A: Cancer statistics, 2019. CA Cancer J Clin 69: 7-34, 2019.

6. Aaronson DS and Horvath CM: A road map for those who don't know JAK-STAT. Science 296: 1653-1655, 2002.

7. Tymoszuk P,Charoentong P,Hackl H,Spilka R, Müller-Holzner E, Trajanoski Z, Obrist P, Revillion F, Peyrat JP, Fiegl H and Doppler W: High STAT1 mRNA levels but not its tyrosine phosphorylation are associated with macrophage infiltration and bad prognosis in breast cancer. BMC Cancer 14: 257, 2014

8. Liu Y, Huang J, Li W, Chen Y, Liu X and Wang J: Meta-analysis of STAT3 and phospho-STAT3 expression and survival of patients with breast cancer. Oncotarget 9: 13060-13067, 2018

9. Cui X, Jing X, Yi Q, Long C, Tan B, Li X, Chen X, Huang Y, Xiang Z, Tian J and Zhu J: Systematic analysis of gene expression alterations and clinical outcomes of STAT3 in cancer. Oncotarget 9: 3198-3213, 2018

10. Han C, Sun B, Zhao X, Zhang Y, Gu Q, Liu F, Zhao N and Wu L: Phosphorylation of STAT3 promotes vasculogenic mimicry by inducing epithelial-to-mesenchymal transition in colorectal cancer. Technol Cancer Res Treat 16: 1209-1219, 2017.

11. Kanehisa M, Sato Y, Furumichi M, Morishima K and Tanabe M: New approach for understanding genome variations in KEGG. Nucleic Acids Res 47(D1): D590-D595, 2019.

12. Kanehisa M, Furumichi M, Tanabe M, Sato Y and Morishima K: KEGG: New perspectives on genomes, pathways, diseases and drugs. Nucleic Acids Res 45(D1): D353-D361, 2017.

13. Kanehisa M and Goto S: KEGG: Kyoto encyclopedia of genes and genomes. Nucleic Acids Res 28: 27-30, 2000.

14. Huang da W, Sherman BT and Lempicki RA: Systematic and integrative analysis of large gene lists using DAVID bioinformatics resources. Nat Protoc 4: 44-57, 2009.

15. Huang da W, Sherman BT and Lempicki RA: Bioinformatics enrichment tools: Paths toward the comprehensive functional analysis of large gene lists. Nucleic Acids Res 37: 1-13, 2009.

16. Mostafavi S, Ray D, Warde-Farley D, Grouios C and Morris Q GeneMANIA: A real-time multiple association network integration algorithm for predicting gene function. Genome Biol 9 (Suppl 1): S4, 2008.

17. Warde-Farley D, Donaldson SL, Comes O, Zuberi K, Badrawi R, Chao P, Franz M, Grouios C, Kazi F, Lopes CT, et al: The GeneMANIA prediction server: Biological network integration for gene prioritization and predicting gene function. Nucleic Acids Res 38: W214-W220, 2010.

18. von Mering C, Huynen M, Jaeggi D, Schmidt S, Bork P and Snel B: STRING: A database of predicted functional associations between proteins. Nucleic Acids Res 31: 258-261, 2003.

19. Szklarczyk D, Morris JH, Cook H, Kuhn M, Wyder S, Simonovic M, Santos A, Doncheva NT, Roth A, Bork P, et al: The STRING database in 2017: Quality-controlled protein-protein association networks, made broadly accessible. Nucleic Acids Res 45(D1): D362-D368, 2017.

20. Subramanian A, Tamayo P, Mootha VK, Mukherjee S, Ebert BL, Gillette MA, Paulovich A, Pomeroy SL, Golub TR, Lander ES and Mesirov JP: Gene set enrichment analysis: A knowledge-based approach for interpreting genome-wide expression profiles. Proc Natl Acad Sci USA 102: 15545-15550, 2005. 
21. Liberzon A, Birger C, Thorvaldsdóttir H, Ghandi M, Mesirov JP and Tamayo P: The molecular signatures database (MSigDB) hallmark gene set collection. Cell Syst 1: 417-425, 2015.

22. Balch CM, Gershenwald JE, Soong SJ, Thompson JF, Atkins MB, Byrd DR, Buzaid AC, Cochran AJ, Coit DG, Ding S, et al: Fina version of 2009 AJCC melanoma staging and classification. J Clin Oncol 27: 6199-6206, 2009.

23. Benjamini Y, Drai D, Elmer G, Kafkafi N and Golani I Controlling the false discovery rate in behavior genetics research. Behav Brain Res 125: 279-284, 2001.

24. Reiner A, Yekutieli D and Benjamini Y: Identifying differentially expressed genes using false discovery rate controlling procedures. Bioinformatics 19: 368-375, 2003.

25. Gerami P, Cook RW, Wilkinson J, Russell MC, Dhillon N, Amaria RN, Gonzalez R, Lyle S, Johnson CE, Oelschlager KM, et al: Development of a prognostic genetic signature to predict the metastatic risk associated with cutaneous melanoma. Clin Cancer Res 21: 175-183, 2015.

26. Ghoreschi K, Laurence A and O'Shea JJ: Janus kinases in immune cell signaling. Immunol Rev 228: 273-287, 2009.

27. Harrison DA: The Jak/STAT pathway. Cold Spring Harb Perspect Biol 4: a011205, 2012.

28. Zoranovic T, Grmai L and Bach EA: Regulation of proliferation, cell competition, and cellular growth by the drosophila JAK-STAT pathway. JAKSTAT 2: e25408, 2013.

29. Rane SG and Reddy EP: Janus kinases: Components of multiple signaling pathways. Oncogene 19: 5662-5679, 2000.

30. Messina JL, Yu H, Riker AI, Munster PN, Jove RL and Daud AI: Activated stat-3 in melanoma. Cancer Control 15: 196-201, 2008

31. Chen X, Du J, Jiang R and Li L: MicroRNA-214 inhibits the proliferation and invasion of lung carcinoma cells by targeting JAK1. Am J Transl Res 10: 1164-1171, 2018.

32. Bi CL, Zhang YQ, Li B, Guo M and Fu YL: MicroRNA-520a-3p suppresses epithelial-mesenchymal transition, invasion, and migration of papillary thyroid carcinoma cells via the JAK1-mediated JAK/STAT signaling pathway. J Cell Physiol 234 4054-467, 2018.

33. Jain N, Zhang T, Fong SL, Lim CP and Cao X: Repression of Stat 3 activity by activation of mitogen-activated protein kinase (MAPK). Oncogene 17: 3157-3167, 1998.

34. Rawlings JS, Rosler KM and Harrison DA: The JAK/STAT signaling pathway. J Cell Sci 117: 1281-1283, 2004.

35. Nissan MH, Pratilas CA, Jones AM, Ramirez R, Won H, Liu C, Tiwari S, Kong L, Hanrahan AJ, Yao Z, et al: Loss of NF1 in cutaneous melanoma is associated with RAS activation and MEK dependence. Cancer Res 74: 2340-2350, 2014.

36. Davies MA and Samuels Y: Analysis of the genome to personalize therapy for melanoma. Oncogene 29: 5545-5555, 2010.

37. Koti M, Siu A, Clément I, Bidarimath M, Turashvili G, Edwards A, Rahimi K, Mes-Masson AM and Squire JA: A distinct pre-existing inflammatory tumour microenvironment is associated with chemotherapy resistance in high-grade serous epithelial ovarian cancer. Br J Cancer 112: 1215-1222, 2015.

38. Simpson JA, Al-Attar A, Watson NF, Scholefield JH, Ilyas M and Durrant LG: Intratumoral T cell infiltration, MHC class I and STAT1 as biomarkers of good prognosis in colorectal cancer. Gut 59: 926-933, 2010.

39. Zhang Y, Molavi O, Su M and Lai R: The clinical and biological significance of STAT1 in esophageal squamous cell carcinoma. BMC Cancer 14: 791, 2014

40. Au KK, Le Page C, Ren R, Meunier L, Clément I, Tyrishkin K, Peterson N, Kendall-Dupont J, Childs T, Francis JA, et al: STAT1-associated intratumoural $\mathrm{T}_{\mathrm{H}} 1$ immunity predicts chemotherapy resistance in high-grade serous ovarian cancer. J Pathol Clin Res 2: 259-270, 2016.

41. Chan SR, Rickert CG, Vermi W, Sheehan KC, Arthur C, Allen JA, White JM, Archambault J, Lonardi S, McDevitt TM, et al: Dysregulated STAT1-SOCS1 control of JAK2 promotes mammary luminal progenitor cell survival and drives ERalpha(+) tumorigenesis. Cell Death Differ 21: 234-246, 2014.

42. Thota B, Arimappamagan A, Kandavel T, Shastry AH, Pandey P, Chandramouli BA, Hegde AS, Kondaiah P and Santosh V: STAT-1 expression is regulated by IGFBP-3 in malignant glioma cells and is a strong predictor of poor survival in patients with glioblastoma. J Neurosurg 121: 374-383, 2014.

43. Arzt L, Kothmaier H, Halbwedl I, Quehenberger F and Popper HH: Signal transducer and activator of transcription 1 (STAT1) acts like an oncogene in malignant pleural mesothelioma. Virchows Arch 465: 79-88, 2014
44. Jung SH, Ahn SY, Choi HW, Shin MG, Lee SS, Yang DH, Ahn JS, Kim YK, Kim HJ and Lee JJ: STAT3 expression is associated with poor survival in non-elderly adult patients with newly diagnosed multiple myeloma. Blood Res 52: 293-299, 2017.

45. Li WM, Huang CN, Lee YC, Chen SH, Lin HH, Wu WJ, Li CC, Yeh HC, Chang LL, Hsu WC and Ke HL: Over-expression of activated signal transducer and activator of transcription 3 predicts poor prognosis in upper tract urothelial carcinoma. Int J Med Sci 14: 1360-1367, 2017

46. Ni Z, Lou W, Lee SO, Dhir R, DeMiguel F, Grandis JR and Gao AC: Selective activation of members of the signal transducers and activators of transcription family in prostate carcinoma. J Urol 167: 1859-1862, 2002.

47. Liu S, Li L, Zhang Y, Zhang Y, Zhao Y, You X, Lin Z, Zhang X and Ye L: The oncoprotein HBXIP uses two pathways to up-regulate S100A4 in promotion of growth and migration of breast cancer cells. J Biol Chem 287: 30228-30239, 2012.

48. Zhou X, Xia Y, Su J and Zhang G: Down-regulation of miR-141 induced by helicobacter pylori promotes the invasion of gastric cancer by targeting STAT4. Cell Physiol Biochem 33: 1003-1012, 2014.

49. Silver DL, Naora H, Liu J, Cheng W and Montell DJ: Activated signal transducer and activator of transcription (STAT) 3: Localization in focal adhesions and function in ovarian cancer cell motility. Cancer Res 64: 3550-3558, 2004.

50. Wang G, Chen JH, Qiang Y, Wang DZ and Chen Z: Decreased STAT4 indicates poor prognosis and enhanced cell proliferation in hepatocellular carcinoma. World J Gastroenterol 21: 3983-3993, 2015.

51. Kuo YH, Chen YT, Tsai HP, Chai CY and Kwan AL: Nucleophosmin overexpression is associated with poor survival in astrocytoma. APMIS 123: 515-522, 2015.

52. Wang CG, Ye YJ, Yuan J, Liu FF, Zhang H and Wang S: EZH2 and STAT6 expression profiles are correlated with colorectal cancer stage and prognosis. World J Gastroenterol 16: 2421-2427, 2010.

53. Nivarthi H, Gordziel C, Themanns M, Kramer N, Eberl M, Rabe B, Schlederer M, Rose-John S, Knösel T, Kenner L, et al: The ratio of STAT1 to STAT3 expression is a determinant of colorectal cancer growth. Oncotarget 7: 51096-51106, 2016.

54. Sun Y, Han Y, Wang X, Wang W, Wang X, Wen M, Xia J, Xing H, Li X and Zhang Z: Correlation of EGFR Del 19 with Fn14/JAK/STAT signaling molecules in non-small cell lung cancer. Oncol Rep 36: 1030-1040, 2016.

55. Jeon M, You D, Bae SY, Kim SW, Nam SJ, Kim HH, Kim S and Lee JE: Dimerization of EGFR and HER2 induces breast cancer cell motility through STAT1-dependent ACTA2 induction. Oncotarget 8: 50570-50581, 2016.

56. Chen G, Wang Y, Wu P, Zhou Y, Yu F, Zhu C, Li Z, Hang Y, Wang K, Li J, et al: Reversibly stabilized polycation nanoparticles for combination treatment of early- and late-stage metastatic breast cancer. ACS Nano 12: 6620-6636, 2018.

57. Merk BC, Owens JL, Lopes MB, Silva CM and Hussaini IM: STAT6 expression in glioblastoma promotes invasive growth. BMC Cancer 11: 184, 2011

58. Sumiyoshi H, Matsushita A, Nakamura Y, Matsuda Y, Ishiwata T, Naito Z and Uchida E: Suppression of STAT5b in pancreatic cancer cells leads to attenuated gemcitabine chemoresistance, adhesion and invasion. Oncol Rep 35: 3216-3226, 2016.

59. Tian X, Guan W, Zhang L, Sun W, Zhou D, Lin Q, Ren W, Nadeem L and Xu G: Physical interaction of STAT1 isoforms with TGF- $\beta$ receptors leads to functional crosstalk between two signaling pathways in epithelial ovarian cancer. J Exp Clin Cancer Res 37: 103, 2018.

60. Wei M, Liu B, Gu Q, Su L, Yu Y and Zhu Z: Stat6 cooperates with $\mathrm{Spl}$ in controlling breast cancer cell proliferation by modulating the expression of p21(Cip1/WAF1) and p27 (Kip1). Cell Oncol (Dordr) 36: 79-93, 2013.

61. Morgan EL, Wasson CW, Hanson L, Kealy D, Pentland I, McGuire V, Scarpini C, Coleman N, Arthur JSC, Parish JL, et al: STAT3 activation by E6 is essential for the differentiation-dependent HPV18 life cycle. PLoS Pathog 14: e1006975, 2018.

62. Hosui A, Klover P, Tatsumi T, Uemura A, Nagano H, Doki Y, Mori M, Hiramatsu N, Kanto T, Hennighausen L, et al: Suppression of signal transducers and activators of transcription 1 in hepatocellular carcinoma is associated with tumor progression. Int J Cancer 131: 2774-2784, 2012.

63. Zhang Y, Cheng X, Liang $\mathrm{H}$ and Jin Z: Long non-coding RNA HOTAIR and STAT3 synergistically regulate the cervical cancer cell migration and invasion. Chem Biol Interact 286: 106-110, 2018 . 
64. Khan MA, El-Gamal MI and $\mathrm{Oh} \mathrm{CH}$ : A progressive review of V600E-B-RAF-dependent melanoma and drugs inhibiting it. Mini Rev Med Chem 17: 351-365, 2017.

65. Liu LJ, Wang W, Huang SY, Hong Y, Li G, Lin S, Tian J, Cai Z, Wang HD, Ma DL and Leung CH: Inhibition of the Ras/Raf interaction and repression of renal cancer xenografts in vivo by an enantiomeric iridium(iii) metal-based compound. Chem Sci 8: 4756-4763, 2017

66. Bosserhoff AK: Novel biomarkers in malignant melanoma. Clin Chim Acta 367: 28-35, 2006

67. Kugel CH III and Aplin AE: Adaptive resistance to RAF inhibitors in melanoma. Pigment Cell Melanoma Res 27: 1032-1038, 2014.
68. Harpio R and Einarsson R: S100 proteins as cancer biomarkers with focus on S100B in malignant melanoma. Clin Biochem 37: 512-518, 2004

69. Xiong TF, Pan FQ and Li D: Expression and clinical significance of S100 family genes in patients with melanoma. Melanoma Res 29: 23-29, 2019.

(i) (2) This work is licensed under a Creative Commons Attribution-NonCommercial-NoDerivatives 4.0 International (CC BY-NC-ND 4.0) License. 